\title{
Influence of mesoscale eddies on the distribution of nitrous oxide in the eastern tropical South Pacific
}

\author{
Damian L. Arévalo-Martínez ${ }^{1}$, Annette Kock ${ }^{1}$, Carolin R. Löscher ${ }^{1,2}$, Ruth A. Schmitz ${ }^{2}$, Lothar Stramma ${ }^{1}$, and \\ Hermann W. Bange ${ }^{1}$ \\ ${ }^{1}$ GEOMAR Helmholtz Centre for Ocean Research Kiel, Düsternbrooker Weg 20, 24105 Kiel, Germany \\ ${ }^{2}$ Institute of Microbiology, Christian Albrechts University of Kiel, Am Botanischen Garten 1-9, 24118 Kiel, Germany \\ Correspondence to: Damian L. Arévalo-Martínez (darevalo@geomar.de)
}

Received: 5 May 2015 - Published in Biogeosciences Discuss.: 19 June 2015

Revised: 3 February 2016 - Accepted: 11 February 2016 - Published: 23 February 2016

\begin{abstract}
Recent observations in the eastern tropical South Pacific (ETSP) have shown the key role of meso- and submesoscale processes (e.g. eddies) in shaping its hydrographic and biogeochemical properties. Off Peru, elevated primary production from coastal upwelling in combination with sluggish ventilation of subsurface waters fuels a prominent oxygen minimum zone $(\mathrm{OMZ})$. Given that nitrous oxide $\left(\mathrm{N}_{2} \mathrm{O}\right)$ production-consumption processes in the water column are sensitive to oxygen $\left(\mathrm{O}_{2}\right)$ concentrations, the ETSP is a region of particular interest to investigate its source-sink dynamics. To date, no detailed surveys linking mesoscale processes and $\mathrm{N}_{2} \mathrm{O}$ distributions as well as their relevance to nitrogen $(\mathrm{N})$ cycling are available. In this study, we present the first measurements of $\mathrm{N}_{2} \mathrm{O}$ across three mesoscale eddies (two mode water or anticyclonic and one cyclonic) which were identified, tracked, and sampled during two surveys carried out in the ETSP in November-December 2012. A two-peak structure was observed for $\mathrm{N}_{2} \mathrm{O}$, wherein the two maxima coincide with the upper and lower boundaries of the OMZ, indicating active nitrification and partial denitrification. This was further supported by the abundances of the key gene for nitrification, ammonium monooxygenase ( $a m o A)$, and the gene marker for $\mathrm{N}_{2} \mathrm{O}$ production during denitrification, nitrite reductase (nirS). Conversely, we found strong $\mathrm{N}_{2} \mathrm{O}$ depletion in the core of the OMZ $\left(\mathrm{O}_{2}<5 \mu \mathrm{mol} \mathrm{L}{ }^{-1}\right)$ to be consistent with nitrite $\left(\mathrm{NO}_{2}^{-}\right)$accumulation and low levels of nitrate $\left(\mathrm{NO}_{3}^{-}\right)$, thus suggesting active denitrification. $\mathrm{N}_{2} \mathrm{O}$ depletion within the OMZ's core was substantially higher in the centre of mode water eddies, supporting the view that eddy activity enhances N-loss processes off Peru, in particular near the shelf break where nutrient-rich, productive waters from up-
\end{abstract}

welling are trapped before being transported offshore. Analysis of eddies during their propagation towards the open ocean showed that, in general, "ageing" of mesoscale eddies tends to decrease $\mathrm{N}_{2} \mathrm{O}$ concentrations through the water column in response to the reduced supply of material to fuel $\mathrm{N}$ loss, although hydrographic variability might also significantly impact the pace of the production-consumption pathways for $\mathrm{N}_{2} \mathrm{O}$. Our results evidence the relevance of mode water eddies for $\mathrm{N}_{2} \mathrm{O}$ distribution, thereby improving our understanding of the N-cycling processes, which are of crucial importance in times of climate change and ocean deoxygenation.

\section{Introduction}

Nitrous oxide $\left(\mathrm{N}_{2} \mathrm{O}\right)$ is an atmospheric trace gas which strongly affects Earth's climate both by contributing to the greenhouse effect and by its role as a major ozone-depleting substance (Ravishankara et al., 2009; Myhre et al., 2013). The ocean is a net source of $\mathrm{N}_{2} \mathrm{O}$ to the atmosphere, accounting for about one-third of the total natural source (Myhre et al., 2013); therefore, the investigation of its formation pathways under changing oceanic regimes is relevant for any future predictions of how the nitrogen $(\mathrm{N})$ cycle will react to future climate change. $\mathrm{N}_{2} \mathrm{O}$ is mainly produced by microbial nitrification and denitrification, with particularly high yields under low-oxygen $\left(\mathrm{O}_{2}\right)$ conditions (Goreau et al., 1980; Naqvi et al., 2010; Löscher et al., 2012; Bakker et al., 2014) such as those found in oxygen minimum zones (OMZs) of the tropical oceans. In the eastern tropical South Pacific (ETSP) a prominent OMZ is 
formed and maintained by the close coupling between elevated primary production fuelled by coastal upwelling and weak ventilation of intermediate waters (Karstensen et al., 2008). Hence, elevated production of $\mathrm{N}_{2} \mathrm{O}$ in subsurface low$\mathrm{O}_{2}$ waters in conjunction with their transport towards the surface makes the ETSP a "hotspot" for emissions of this climate-relevant gas to the atmosphere (Arévalo-Martínez et al., 2015). However, even though $\mathrm{N}_{2} \mathrm{O}$ production in low- $\mathrm{O}_{2}$ waters could supply as much as $25-50 \%$ of the global ocean source (Suntharalingam et al., 2000), it has been shown that when $\mathrm{O}_{2}$ concentrations fall below about $5 \mu \mathrm{mol} \mathrm{L}-1$ (in the OMZ's core) $\mathrm{N}_{2} \mathrm{O}$ consumption through denitrification $\left(\mathrm{NO}_{3}^{-} \rightarrow \mathrm{NO}_{2}^{-} \rightarrow \mathrm{NO} \rightarrow \mathrm{N}_{2} \mathrm{O} \rightarrow \mathrm{N}_{2}\right)$ takes place, and therefore these waters may act as a net sink for this gas (Codispoti and Christensen, 1985; Löscher et al., 2015b). Hence, OMZs have a significant role in the marine $\mathrm{N}$ cycle not only due to their influence on the subsurface production of climate-relevant trace gases such as $\mathrm{N}_{2} \mathrm{O}$ (Paulmier et al., 2008; Codispoti, 2010; Capone and Hutchins, 2013) but also because of their contribution to the loss of bioavailable fixed N (Kalvelage et al., 2013; Dalsgaard et al., 2014). Further ocean deoxygenation as well as expansion of the OMZs worldwide could in turn increase the volume of waters in which N loss takes place (Stramma et al., 2010; Deutsch et al., 2011), thereby intensifying $\mathrm{N}$ limitation of primary production and reducing the ocean's ability to sequester atmospheric $\mathrm{CO}_{2}$ (Falkowski, 1997).

Recent observations have shown the important role of mesoscale processes in the distribution of hydrographic and biogeochemical properties of the ETSP (Stramma et al., 2013, 2014; Bourbonnais et al., 2015; Löscher et al., 2015a; Thomsen et al., 2015). Along the Peruvian coast, instabilities of the main current flow lead to the formation of non-linear mesoscale eddies which propagate offshore from the site of formation, significantly contributing to the cross-shelf transport of heat, mass, momentum, and biogeochemical properties (Chelton et al., 2007; Chaigneau et al., 2008). Likewise, offshore propagation of mesoscale eddies has been shown to increase the spatial extent of the high-productivity area of the coastal upwelling (Correa-Ramirez et al., 2007; Chelton et al., 2011), implying their relevance in the export of carbon to the open ocean. Provided that downward transport of organic matter is an essential control of the marine $\mathrm{N}$ cycle (Kalvelage et al., 2013), it is of interest to investigate potential changes in $\mathrm{N}_{2} \mathrm{O}$ distribution within mesoscale eddies. Although such mesoscale features in the OMZ off Peru have been associated with N-loss processes (Altabet et al., 2012; Stramma et al., 2013), to date no detailed surveys linking mesoscale eddies and $\mathrm{N}_{2} \mathrm{O}$ as well as their relevance to $\mathrm{N}$ cycling are available.

The main goal of this study is to present the first set of $\mathrm{N}_{2} \mathrm{O}$ measurements collected across three mesoscale eddies which were tracked during the R/V Meteor cruises M90 and M91 in November-December 2012. Furthermore, we use a combination of $\mathrm{N}_{2} \mathrm{O}$ concentrations and abundance of selected

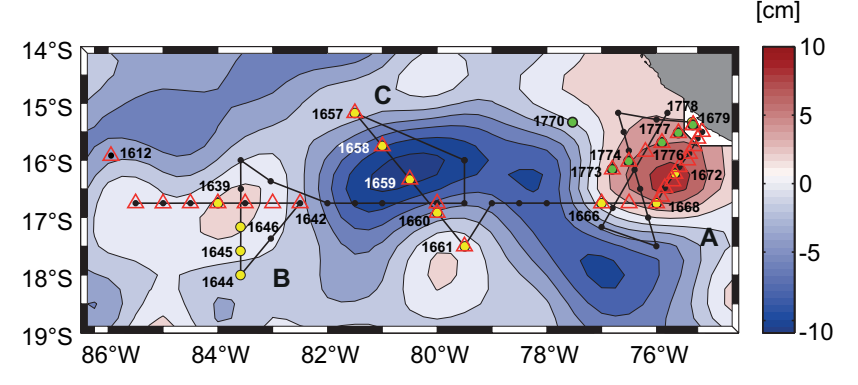

Figure 1. Map of sampling locations in the ETSP. Aviso sea level height anomaly for 21 November 2012 is shown (anticyclonic eddies are depicted in red, and cyclonic in blue). The cruise track and CTD stations with bottle sampling from the M90 cruise are shown in black. Open triangles indicate the hydrographic stations shown in Fig. 2. Sampling stations within the mode water eddies A and B as well as the open-ocean cyclonic eddy $\mathrm{C}$ are highlighted in yellow, whereas the cross-shelf section carried out during the M91 cruise is displayed in green. Station 1770 from the M91 cruise was used for the molecular work shown in Fig. 5.

molecular markers (key genes) for its main formation pathways to elucidate the causes of the observed distribution. Finally, we compare the $\mathrm{N}_{2} \mathrm{O}$ concentrations within the centre of "young" and "old" mesoscale eddies in order to identify the net effect of their "ageing" (offshore propagation).

\section{Eddy surveys}

The fieldwork was conducted in November-December 2012 during the R/V Meteor cruises M90 and M91, which covered the open ocean and shelf areas off Peru $\left(5-25^{\circ} \mathrm{S}, 75-86^{\circ} \mathrm{W}\right)$. Detailed physical and biogeochemical surveys of mesoscale eddies were carried out within $14-18^{\circ} \mathrm{S}$ and $75-84^{\circ} \mathrm{W}$ on 16 to 25 November and on 19 to 23 December. Based on near-real-time satellite data of sea level height anomalies (SSHAs) from Aviso (http://aviso.altimetry.fr/), it was possible to identify two mode water (anticyclonic) eddies at the shelf break (eddy A) and in the open ocean (eddy B), as well as one cyclonic eddy (eddy C) in the open ocean. Likewise, SSHA data were used to track and revisit eddy A in order to investigate its property's distribution after it started to move westward across the shelf break (Fig. 1).

\subsection{Oceanographic and biogeochemical measurements}

Ocean velocities were recorded by means of two RDI Ocean Surveyor acoustic Doppler current profilers (ADCPs), which provided velocity data down to about 700 and $1200 \mathrm{~m}$ depth (75 and $38 \mathrm{kHz}$, respectively). Discrete water sampling as well as profiling of hydrographic properties was carried out by means of a Sea-Bird CTD-Rosette equipped with $10 \mathrm{~L}$ Niskin bottles and double sensors for temperature, conductivity, and $\mathrm{O}_{2}$. Seawater samples for discrete $\mathrm{O}_{2}$ measurements were collected by drawing bubble-free samples from 
(a)
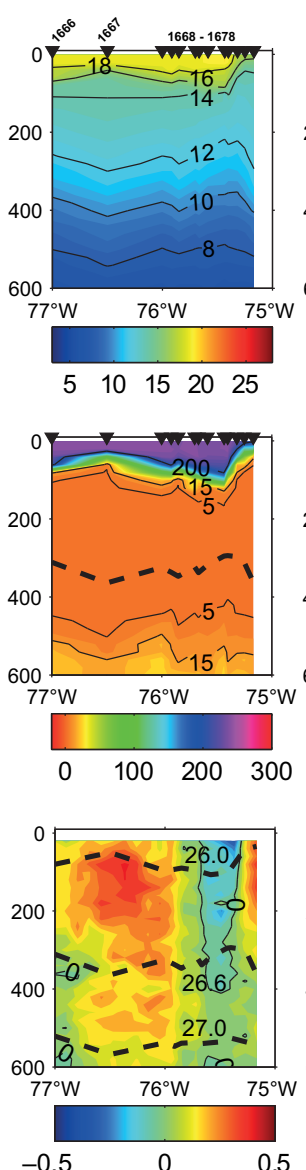

(b)
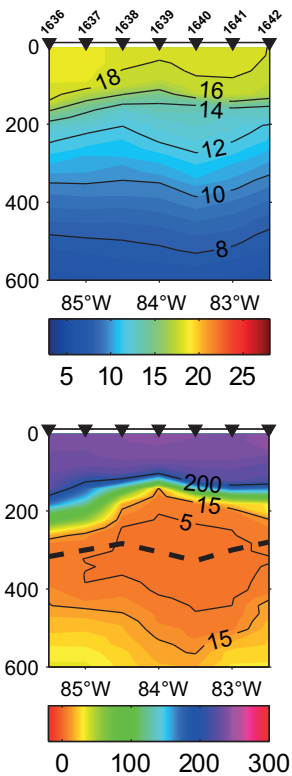

(c)
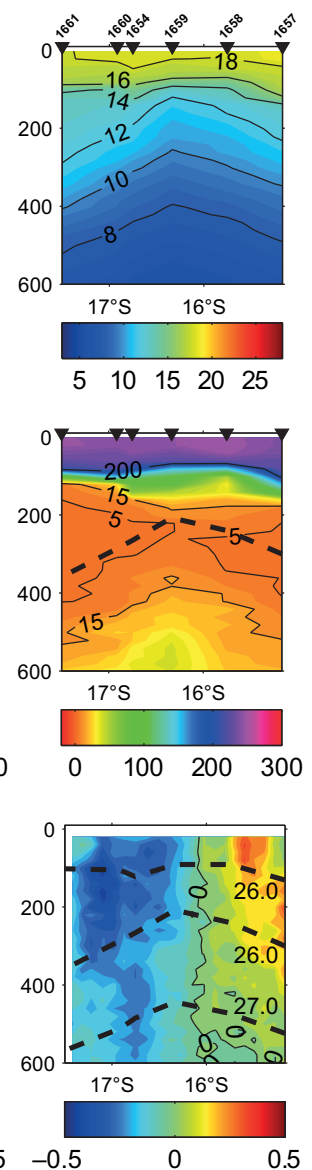

(d)
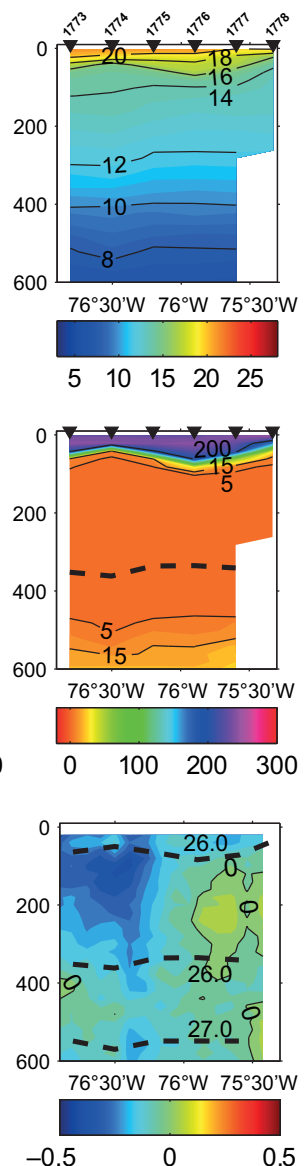

Figure 2. Hydrographic conditions at the time of sampling in the ETSP $\left(0-600 \mathrm{~m}\right.$ depth). Temperature in ${ }^{\circ} \mathrm{C}$ (upper panels), $\mathrm{O}_{2}$ in $\mu \mathrm{mol} \mathrm{kg}^{-1}$ (middle panels), and zonal (a, c, d) as well as meridional. (b) velocity in $\mathrm{m} \mathrm{s}^{-1}$ (lower panels) for eddies A, B, and C during the M90 cruise (November 2012; a-c), as well as for eddy A during the M91 cruise (December 2012; d) are shown. Locations of CTD profiles are marked by black triangles (cf. Fig. 1), and the isopycnal $\sigma_{\theta}=26.6 \mathrm{~kg} \mathrm{~m}^{-3}$ near the core of the $\mathrm{OMZ}$ is included in the $\mathrm{O}_{2}$ sections as a black dashed line. Dashed lines in the velocity plots indicate potential density.

the CTD/Rosette system. $\mathrm{O}_{2}$ concentrations of these samples were determined by the Winkler method (Hansen, 1999) and were used to calibrate the $\mathrm{O}_{2}$ sensors. The overall precision of the $\mathrm{O}_{2}$ discrete measurements was $\pm 0.45 \mu \mathrm{mol} \mathrm{L}^{-1}$. Nitrate $\left(\mathrm{NO}_{3}^{-}\right)$, nitrite $\left(\mathrm{NO}_{2}^{-}\right)$, and phosphate $\left(\mathrm{PO}_{4}^{-3}\right)$ concentrations were measured on board by means of a QuAAtro auto-analyser (SEAL Analytical $\mathrm{GmbH}$, Germany) with an overall precision of $\pm 0.1 \mu \mathrm{mol} \mathrm{L}-1 \quad\left(\mathrm{NO}_{3}^{-}\right.$and $\left.\mathrm{NO}_{2}^{-}\right)$ and $\pm 0.02 \mu \mathrm{mol} \mathrm{L}^{-1}\left(\mathrm{PO}_{4}^{3-}\right)$. The $\mathrm{N}$ deficit (or $\mathrm{N}^{*}$ ) was computed as $\left[\mathrm{NO}_{3}^{-}\right]+\left[\mathrm{NO}_{2}^{-}\right]-16 \times\left[\mathrm{PO}_{4}^{-3}\right]$. Chlorophyll a $(\mathrm{Chl} a)$ concentrations were determined by the acetone extraction method followed by fluorometric analysis with a Trilogy ${ }^{\circledR}$ laboratory fluorometer (Welschmeyer, 1994). Turbidity was measured by means of a factory-calibrated WET Labs fluorometer-turbidity sensor with sensitivity up to $0.01 \mathrm{NTU}$ (nephelometric turbidity units). Discrete $\mathrm{N}_{2} \mathrm{O}$ samples were collected at 22 stations with emphasis on the upper $1000 \mathrm{~m}$ of the water column. For this purpose, bubblefree, triplicate samples were collected in $20 \mathrm{~mL}$ brown glass flasks and sealed with rubber butyl septa and metallic caps to avoid any gas exchange. Subsequently, a headspace was created in each flask by injecting $10 \mathrm{~mL}$ of helium $(99.999 \%$, AirLiquide GmbH, Düsseldorf, Germany). Microbial activity within the samples was prevented by adding $50 \mu \mathrm{L}$ of a $1: 3$ dilution from a saturated mercuric chloride $\left(\mathrm{HgCl}_{2}\right)$ solution. After an equilibration period of a minimum of $2 \mathrm{~h}$ the samples were analysed using a gas chromatograph (Hewlett Packard (HP) 5890 Series II) with electron capture detector (GC-ECD). The separation procedure was carried out in a stainless-steel column (length: $1.83 \mathrm{~m}$; external diameter: $3.2 \mathrm{~mm}$; internal diameter: $2.2 \mathrm{~mm}$ ) with a molecular sieve of $5 \AA$ (W. R. Grace \& Co. Conn., Columbia, USA). The GCECD was calibrated daily by using dilutions of at least three standard gas mixtures up to $10400 \mathrm{ppb}$ (Deuste Steininger $\mathrm{GmbH}$, Mühlheim, Germany). Standard gases with $\mathrm{N}_{2} \mathrm{O}$ 
$<1000$ ppb were calibrated at the department of atmospheric chemistry of the Max Plank Institute for Biogeochemistry (Jena, Germany) against the NOAA 2006 scale, whereas for $\mathrm{N}_{2} \mathrm{O}>1000 \mathrm{ppb}$ the gas molar fraction was determined by means of high-resolution measurements of a calibrated offaxis integrated cavity output spectroscopy (OA-ICOS) analyser (precision better than $0.3 \mathrm{ppb}$; Arévalo-Martínez, et al., 2013). Calculation of the $\mathrm{N}_{2} \mathrm{O}$ concentrations was done as described by Walter et al. (2006). In order to obtain background $\mathrm{N}_{2} \mathrm{O}$ concentrations for the ETSP at the time of sampling, we used data from Kock et al. (2016). For this, we computed a mean profile by averaging water column concentrations of $\mathrm{N}_{2} \mathrm{O}$ from stations located in the open ocean $\left(86^{\circ} \mathrm{W}\right.$ section) between 6 and $16^{\circ} \mathrm{S}$. We did not include near-coastal stations for the background profile calculation due to the high variability that can be observed, since this hampers any attempts of obtaining a "typical" profile (see Kock et al., 2016). Our designation of particular stations to eddy cores and edges was based on the SSHA data and follows the criteria defined by Stramma et al. (2013). Eddy core anomalies for oceanographic and biogeochemical parameters were computed as the difference between stations located at or near the centre of the eddy and stations outside of it.

\subsection{Molecular genetic methods}

Nucleic acids samples were collected by filtering up to $1 \mathrm{~L}$ of seawater (exact volumes were recorded, and the filtration time was lower than $20 \mathrm{~min}$ ) onto polycarbonate membrane filters with a pore size of $0.2 \mu \mathrm{m}$ (Millipore). Immediately after collection, samples were frozen at $-80^{\circ} \mathrm{C}$ until further processing. Nucleic acids were extracted using the AllPrep DNA/RNA Mini Kit (Qiagen, Hildesheim, Germany) with additional $15 \mathrm{~min}$ cell lysis $\left(10 \mathrm{mg} \mathrm{mL}^{-1}\right.$ lysozyme in $10 \mathrm{mM}$ Tris-EDTA, pH 8) and shock freezing in liquid nitrogen before extraction. Quantitative $(q)$ PCR followed protocols in Löscher et al. (2014) except that a ViiA7 qPCR system (Life Technologies, Carlsbad, CA, USA) was used. The sensitivity level for the detection of ammonium monooxygenase ( $a m o A$ ) and hydrazine oxidoreductase $(h z o)$ genes with this method is 4 copies $\mathrm{L}^{-1}$, whereas for the nitrite reductase (nirS) gene it is 1 copy $\mathrm{L}^{-1}$.

\section{Hydrographic and biogeochemical setting}

The properties of the eddies investigated during the M90 (November 2012) and M91 (December 2012) cruises were described in detail by Stramma et al. (2013), and therefore only the main features are briefly mentioned here. Eddy A was centred at about $16^{\circ} \mathrm{S}, 76^{\circ} \mathrm{W}$, with the highest intensity (zonal and meridional velocities) in the upper $600 \mathrm{~m}$. As a typical mode water eddy, lifting (deepening) of the seasonal (main) pycnocline could be observed (McGillicuddy Jr. et al., 2007), whereby $\mathrm{O}_{2}$ was lower and temperature and salinity were higher in the centre of the eddy than at its edges (Fig. 2).
Shoaling of the mixed-layer depth in the centre of eddy A coincided with a high Chl $a$ maximum at about $50 \mathrm{~m}$ depth and an up to $30 \%$ reduction in $\mathrm{O}_{2}$ concentrations. The outer western side of cross-shelf sections across eddy A also revealed the influence of coastal upwelling near the shelf break in the upper $180 \mathrm{~m}$. However this feature was detached from the eddy itself as is shown by temperature, $\mathrm{O}_{2}$, and velocity distributions (Fig. 2). Meridional velocity distributions as well as temperature, salinity, and density fields suggest that eddy A enclosed waters from the Peru-Chile Undercurrent (PCU) at the time of formation near the shelf (Stramma et al., 2013). Eddy B was centred in the open ocean at about $17^{\circ} \mathrm{S}, 83^{\circ} 30^{\prime} \mathrm{W}$. Although the velocity distribution was similar to that of eddy A (strong in the upper $600 \mathrm{~m}$ ), rotational speeds were lower and the temperature, salinity, and density anomalies were weaker than in eddy A. Moreover, in comparison with eddy $\mathrm{A}$, the depth of uplifting isopycnals and the mixed-layer depth were deeper in eddy B (Fig. 2). As a consequence, the $\mathrm{Chl} a$ maximum as well as the temperature and $\mathrm{O}_{2}$ anomalies could be found $100 \mathrm{~m}$ deeper in eddy $\mathrm{B}$ than in eddy A. A trajectory analysis indicated that eddy B was formed near the shelf about 5 months before the time of sampling (i.e. 3 months older than eddy A); however a precise location could not be determined with our methods (Stramma et al., 2013). Eddy C was centred in the open ocean at $16^{\circ} 15^{\prime} \mathrm{S}, 80^{\circ} 15^{\prime} \mathrm{W}$, with maximum velocities at ca. $50 \mathrm{~m}$ depth and a positive density anomaly over the upper $600 \mathrm{~m}$. In contrast to the anticyclonic eddies $\mathrm{A}$ and $\mathrm{B}$, temperature and salinity of eddy $\mathrm{C}$ were lower, and density was higher in the centre than at its edges (Fig. 2), although the magnitude of the anomalies was similar to those of eddy A (Stramma et al., 2013). Furthermore, $\mathrm{O}_{2}$ concentrations were higher in the centre of the eddy than at the edges, and the size of the $\mathrm{O}_{2}$ anomaly in the $\mathrm{OMZ}$ was larger than for eddy A, indicating ventilation of the $\mathrm{OMZ}$ with waters from below the main thermocline. Eddy $\mathrm{C}$ was formed at the coast, but unlike the anticyclones it moved westward without staying at the shelf (Stramma et al., 2013).

\section{Results and discussion}

\subsection{Depth distribution of $\mathrm{N}_{2} \mathrm{O}$}

$\mathrm{N}_{2} \mathrm{O}$ concentrations in the water column featured a two-peak structure with maxima $\mathrm{N}_{2} \mathrm{O}$ concentrations at the upper and lower boundaries of the OMZ, and depletion at the OMZ's core (Fig. 3). Such a pattern has been previously reported for the ETSP (Farías et al., 2007) and similar systems with prominent OMZs (Bange et al., 2001; Bange et al., 2010), and it is generally ascribed to alternating activity of microbial $\mathrm{N}_{2} \mathrm{O}$ production-consumption pathways along the vertical $\mathrm{O}_{2}$ gradients (Codispoti and Christensen, 1985; Ji et al., 2015). Although elevated $\mathrm{N}_{2} \mathrm{O}$ concentrations were observed in near-surface waters (up to $88 \mathrm{nmol} \mathrm{L}^{-1}$ ) of the northwestern edge of eddy $\mathrm{A}$, at the time of sampling the 
(a)

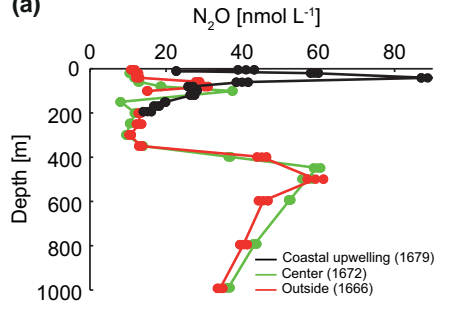

(d)

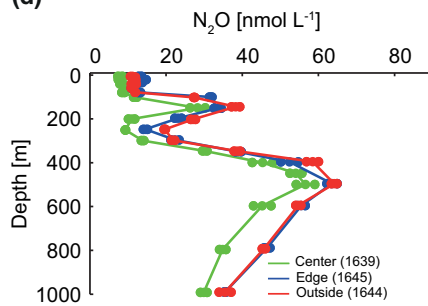

(g)

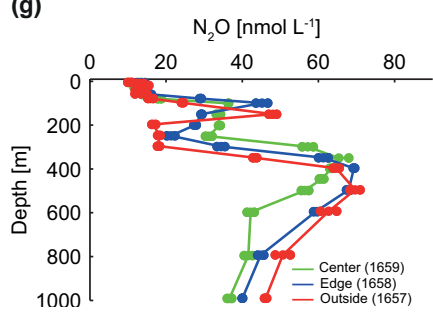

(b)

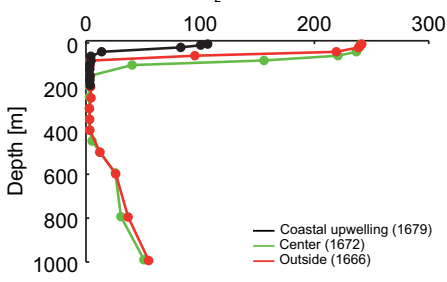

(e)

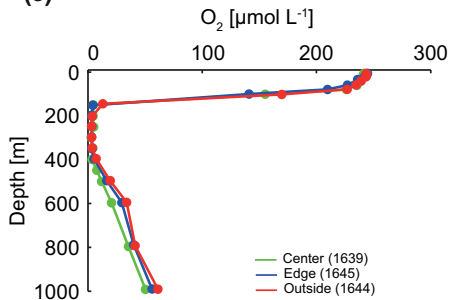

(h)

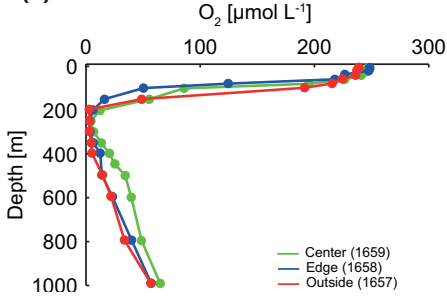

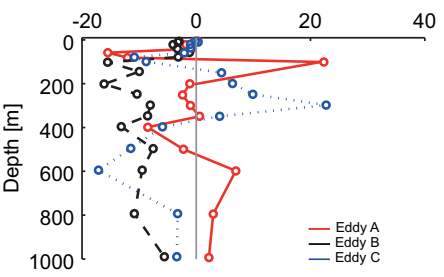

(f)

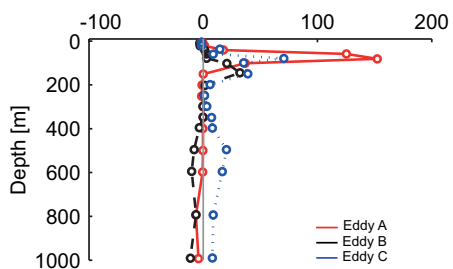

(i)

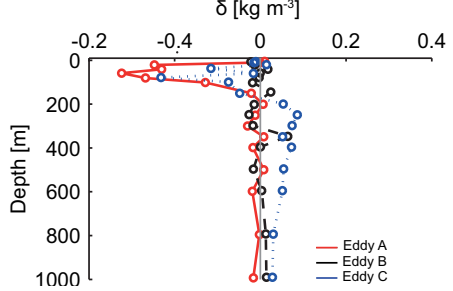

Figure 3. Vertical of distribution of $\mathrm{N}_{2} \mathrm{O}$ and $\mathrm{O}_{2}$ across the mode water eddies $\mathrm{A}(\mathbf{a}-\mathbf{b})$ and $\mathrm{B}(\mathbf{d}-\mathbf{e})$, and the cyclonic eddy $\mathrm{C}$ (g-h) during the M90 cruise in November 2012. Selected depth profiles of $\mathrm{N}_{2} \mathrm{O}$ and $\mathrm{O}_{2}$ are shown in (a, d, $\left.\mathbf{g}\right)$ and (b, e, h), respectively. Black lines/symbols in (a) and (b) indicate the northwesternmost station of eddy $\mathrm{A}$, at which the influence of coastal upwelling was observed. Numbers in parentheses indicate the station numbers (cf. Fig. 1). For $\mathrm{N}_{2} \mathrm{O}$ the standard deviation from triplicate samples is depicted by circles around the concentration values at each depth. $\mathrm{N}_{2} \mathrm{O}, \mathrm{O}_{2}$, and density $(\delta)$ core anomalies for the eddies sampled during $\mathrm{M} 90$ are shown in (c), (f), and (i), respectively.

eddy was already detached from the coast, and thus these high concentrations could be rather associated to coastal upwelling. In agreement with the distribution of physical properties (Fig. 2), the vertical extent of the low- $\mathrm{N}_{2} \mathrm{O}$ waters from the OMZ's core was shifted to shallower depths within the centre of mode water eddies A and B. Moreover, shallower minima of $\mathrm{N}_{2} \mathrm{O}$ were observed in the upper OMZ for stations located in the centre of eddy A $\left(150 \mathrm{~m}, \sigma_{\theta}=26.3 \mathrm{~kg} \mathrm{~m}^{-3}\right)$ compared to eddy B $\left(250 \mathrm{~m}, \sigma_{\theta}=26.5 \mathrm{~kg} \mathrm{~m}^{-3}\right)$, whereas in both cases the second $\mathrm{N}_{2} \mathrm{O}$ maxima were only slightly displaced towards deeper depths. $\mathrm{N}_{2} \mathrm{O}$ concentrations at the boundaries of the $\mathrm{OMZ}$ in the centre of eddy A were similar to those at its edge, whereas for eddy $\mathrm{B}$ the $\mathrm{N}_{2} \mathrm{O}$ concentrations in the centre were markedly lower than at its edge and outside of it. This is reflected by stronger (negative) $\mathrm{N}_{2} \mathrm{O}$ anomalies in eddy B than in eddy A (Fig. 3). Even though the highest velocities for both eddies could be measured until about $600 \mathrm{~m}$ depth $\left(\sigma_{\theta}=26.7 \mathrm{~kg} \mathrm{~m}^{-3}\right)$, the $\mathrm{O}_{2}$, temperature, and salinity anomalies in eddy $\mathrm{B}$ persisted at deeper depths, which could explain why the $\mathrm{N}_{2} \mathrm{O}$ concentrations at the cen- tre of eddy B were generally lower through the water column (see Fig. 3 and Fig. S1 in the Supplement). The lowest $\mathrm{N}_{2} \mathrm{O}$ concentration anomalies were found at the core of the OMZ (defined as the depth range with $\mathrm{O}_{2}<\sim 5 \mu \mathrm{mol} \mathrm{L}{ }^{-1}$ ) both at the coastal and open-ocean stations (Fig. 3), suggesting enhanced $\mathrm{N}_{2} \mathrm{O}$ depletion within the centre of eddies $\mathrm{A}$ and $\mathrm{B}$.

Recently, Stramma et al. (2013) reported the occurrence of active $\mathrm{N}$-loss processes at the core of the $\mathrm{OMZ}$ within the centre of both eddies A and B based on the co-occurrence of pronounced $\mathrm{NO}_{2}^{-}$maxima as well as $\mathrm{O}_{2}$ and $\mathrm{NO}_{3}^{-}$minima. In their work, Stramma et al. (2013) argued that nutrient subduction along with reduced productivity might have reduced the flux of organic matter that could fuel $\mathrm{N}$ cycling when the eddies moved towards the open ocean. According to this, a comparatively lower consumption of $\mathrm{N}_{2} \mathrm{O}$ by denitrification within the OMZ in the centre of eddy $\mathrm{B}$ should diminish the differences between profiles inside and outside. However, this effect was not visible in the $\mathrm{N}_{2} \mathrm{O}$ distribution, and, conversely, $\mathrm{N}_{2} \mathrm{O}$ concentrations were generally lower in the centre of eddy B than in the centre of eddy A. While depth- 
integrated $\mathrm{N}_{2} \mathrm{O}$ concentration in the $\mathrm{OMZ}$ within the openocean eddy B was only $6 \%$ lower than in coastal eddy A, observed differences were as high as $25 \%$ when the entire water column $(5-1000 \mathrm{~m})$ was considered. Integrated concentrations of $\mathrm{O}_{2}$ were generally lower in eddy A than in eddy $\mathrm{B}$ $\left(37.6 \pm 1.7 \mathrm{~mol} \mathrm{~m}^{-2}\right.$ and $46.9 \pm 7.2 \mathrm{~mol} \mathrm{~m}^{-2}$, respectively), suggesting the potential for enhanced $\mathrm{N}_{2} \mathrm{O}$ production at the oxic-suboxic boundaries of eddy A (see also Sect. 4.2). However, the extent to which these $\mathrm{O}_{2}$ concentration differences could explain the observed differences in $\mathrm{N}_{2} \mathrm{O}$ concentrations cannot be quantitatively assessed from our data, in particular because of the sampling station density and the fact that we did not carry out $\mathrm{N}_{2} \mathrm{O}$ production rate measurements. Hence, although Stramma et al. (2013) reported a reduction in organic matter turnover for the open-ocean eddy $\mathrm{B}$ during the M90 cruise, this was not evident for $\mathrm{N}_{2} \mathrm{O}$, which probably reflects either (1) dissimilarities of the water masses in both eddies at the time of formation (see also Sect. 4.3) or (2) slower denitrification rates at the edges of eddy B than in its centre. A decreased pace of denitrification could explain the higher $\mathrm{N}_{2} \mathrm{O}$ concentration in the OMZ from stations outside of eddy $\mathrm{B}$ than those in its centre because it would imply slower $\mathrm{N}_{2} \mathrm{O}$ consumption (transformation to $\mathrm{N}_{2}$ ).

Vertical distribution of $\mathrm{N}_{2} \mathrm{O}$ in eddy $\mathrm{C}$ was similar to that of the two anticyclonic eddies, with doming of isopycnals in its centre causing a shift of the upper and lower $\mathrm{N}_{2} \mathrm{O}$ maxima, albeit in this case towards shallower depths. We found elevated $\mathrm{N}_{2} \mathrm{O}$ concentrations at the boundaries of the $\mathrm{OMZ}$ and only a slight decrease at $150-400 \mathrm{~m}$ depth, where $\mathrm{O}_{2}$ concentrations fell below $5 \mu \mathrm{mol} \mathrm{L}^{-1}$ (Fig. 3). Nonetheless, the $\mathrm{N}_{2} \mathrm{O}$ minimum was less pronounced than for eddies A and B at the core of the $\mathrm{OMZ}$, where the strongest (positive) anomalies could be found (Fig. 3). Our results are consistent with the observations of Stramma et al. (2013), who reported elevated $\mathrm{O}_{2}$ concentrations as well as low $\mathrm{NO}_{2}^{-}$accumulation at the centre of eddy $\mathrm{C}$, suggesting lower activity of $\mathrm{N}$-loss processes than in eddies A and B. Although upon formation cyclonic eddies tend to increase subsurface production just as mode water eddies do, this effect is not long-lasting and the net downwelling of nutrients ultimately leads to decreased primary productivity (McGillicuddy Jr. et al., 2007). Thus, the diminished supply of organic matter which could fuel $\mathrm{N}$ loss within the OMZ's core might have contributed to the relatively higher $\mathrm{N}_{2} \mathrm{O}$ concentrations in the $\mathrm{OMZ}$ of eddy $\mathrm{C}$ than in eddies A and B. Analysis of SSHA data showed, however, that stations assumed to be located at the edge and outside of eddy $\mathrm{C}$ were actually influenced by another anticyclonic eddy (see Fig. 1) and therefore are not representative of the mean conditions at the ETSP. Hence, more detailed (higher temporal and spatial resolution) studies of the distribution of $\mathrm{N}_{2} \mathrm{O}$ within cyclonic eddies are needed in order to elucidate their role in the water column distribution of this gas in the ETSP.

Both our maximum and minimum of $\mathrm{N}_{2} \mathrm{O}$ concentrations along the vertical $\mathrm{O}_{2}$ gradients were well within the range of previous observations in the ETSP (Farías et al., 2007, 2009; Ryabenko et al., 2012; Kock et al., 2016), and no statistically significant differences (two-sample $t$ test, $p$ values $>0.05$, $\alpha=0.05$ ) were found between our $\mathrm{N}_{2} \mathrm{O}$ values at the centre of the three eddies and a mean open-ocean profile along the $86^{\circ} \mathrm{W}$ section (Fig. S2). If only stations at about $16^{\circ} \mathrm{S}$ are considered, however, it can be seen that $\mathrm{N}_{2} \mathrm{O}$ depletion at the core of the OMZ was stronger at the centre of eddies A and B than outside of them (Fig. S2). Hence, although the influence of eddies on the $\mathrm{N}_{2} \mathrm{O}$ distribution in the ETSP as a whole seems to be masked by the high variability of the large-scale distribution of $\mathrm{N}_{2} \mathrm{O}$ (see Kock et al., 2016), the negative $\mathrm{N}_{2} \mathrm{O}$ anomalies within the core of the $\mathrm{OMZ}$ at the centre of anticyclonic eddies suggest a locally enhanced sink for this gas.

Given that enhanced concentrations of $\mathrm{N}_{2} \mathrm{O}$ can be found within the upper oxycline of the ETSP (e.g. Fig. 3), shoaling of the thermocline within mode water eddies would mean higher $\mathrm{N}_{2} \mathrm{O}$ concentrations for a given depth as compared to a background profile. Likewise, coastal upwelling waters off Peru are a known source of extremely high $\mathrm{N}_{2} \mathrm{O}$ concentrations to the surface (Arévalo-Martínez et al., 2015). However, since the observed eddies were detached from the coast at the time of sampling, the eddy-driven shoaling of waters with relatively high $\mathrm{N}_{2} \mathrm{O}$ concentrations did not contribute to surface fluxes to the atmosphere in this location. In support of this, we observed that even in coastal stations, where a rapid decrease in $\mathrm{O}_{2}$ concentrations $(\mathrm{OMZ}$ starts at about $15 \mathrm{~m}$ depth) was followed by a narrow peak of $\mathrm{N}_{2} \mathrm{O}$ between 10 and $40 \mathrm{~m}$ depth (Fig. 3), there was not any appreciable variation of $\mathrm{N}_{2} \mathrm{O}$ concentrations at the surface. Independent verification of our bottle data derives from surface $(\sim 6 \mathrm{~m})$ underway measurements performed during the same cruises (Arévalo-Martínez et al., 2015), which also did not show any enhancement of $\mathrm{N}_{2} \mathrm{O}$ concentrations during the several crosseddy sections carried out as part of the M90 and M91 cruises. Hence, although mesoscale eddies seem to influence the vertical distribution of $\mathrm{N}_{2} \mathrm{O}$, they do not have a direct impact on its surface distribution and emissions to the atmosphere since they are "trapped" below the mixed layer.

\section{2 $\quad \mathrm{N}_{2} \mathrm{O}$ cycling within coastal eddy $\mathrm{A}$}

SSHA data from December 2012 indicated that coastal mode water eddy A was still centred near the shelf break at about $16^{\circ} 30^{\prime} \mathrm{S}, 76^{\circ} 30^{\prime} \mathrm{W}$. The $\mathrm{O}_{2}$ distribution along a cross-shelf section between $16^{\circ} 9^{\prime} \mathrm{S}, 76^{\circ} 50^{\prime} \mathrm{W}$ and $15^{\circ} 23^{\prime} \mathrm{S}, 75^{\circ} 20^{\prime} \mathrm{W}$ revealed $\mathrm{O}_{2}$ minima $\left(<5 \mu \mathrm{mol} \mathrm{L}{ }^{-1}\right)$ not only in the centre of eddy A but also in the vicinity of the shelf break due to coastal upwelling. (Fig. 4). An intermediate-depth low- $\mathrm{N}_{2} \mathrm{O}$ layer was consistent with the location of these low- $\mathrm{O}_{2}$ waters, and it reached its maximum extension (70-400 $\mathrm{m}$ depth) close to the western side of the eddy A centre. Although a strong maximum of $\mathrm{N}_{2} \mathrm{O}$ (up to $80 \mathrm{nmol} \mathrm{L}^{-1}$ ) could be observed at about $40 \mathrm{~m}$ depth within the station located in the 
(a)

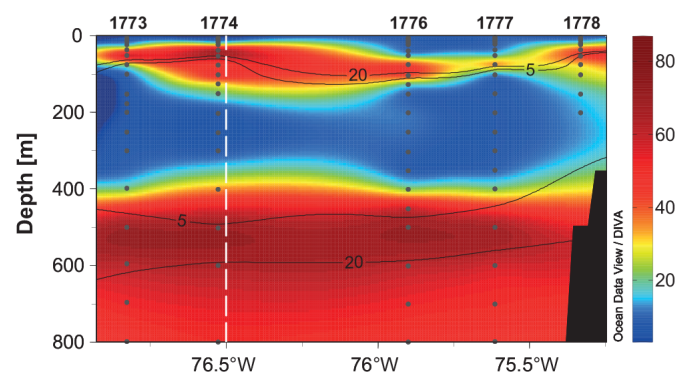

(c)

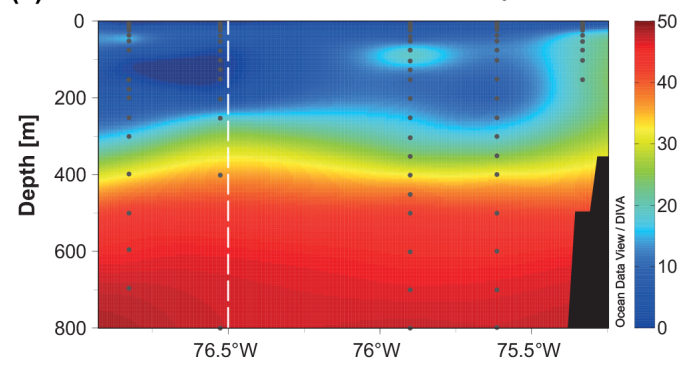

(b)

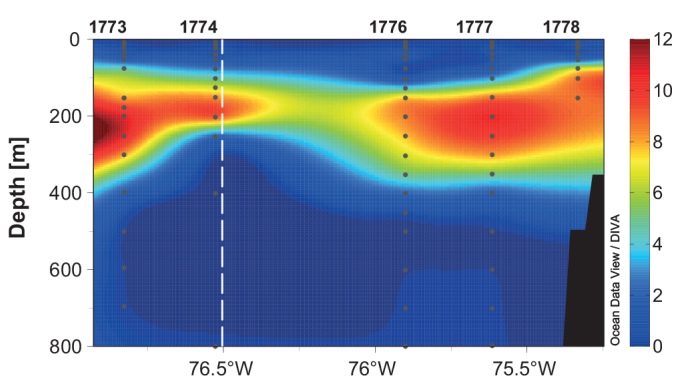

(d)

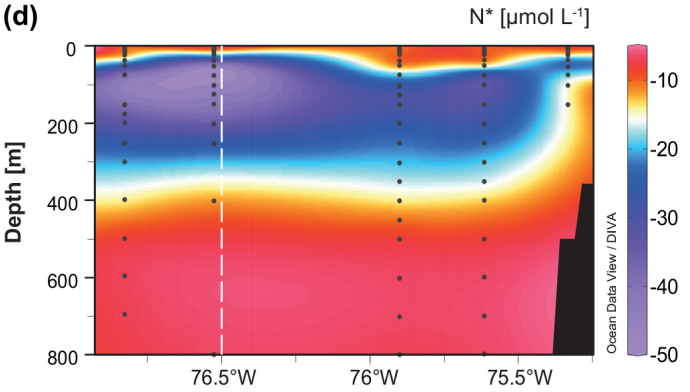

Figure 4. Cross-shelf distribution of $\mathrm{N}_{2} \mathrm{O}(\mathbf{a}), \mathrm{NO}_{2}^{-}$(b), $\mathrm{NO}_{3}^{-}$(c), and $\mathrm{N}^{*}$ (d) along eddy $\mathrm{A}$ in December $2012\left(16.2^{\circ} \mathrm{S}, 76.9^{\circ} \mathrm{W}\right.$ to $15.3^{\circ} \mathrm{S}$ $75.2^{\circ} \mathrm{W}$; see Fig. 1). Contours in (a) represent $\mathrm{O}_{2}$ concentrations (in $\mu \mathrm{mol} \mathrm{L}{ }^{-1}$ ). The white dashed lines indicate the approximate location of the eddy centre according to SSHA data. Numbers above panels (a) and (b) are the station numbers (cf. Fig. 1).

(a)

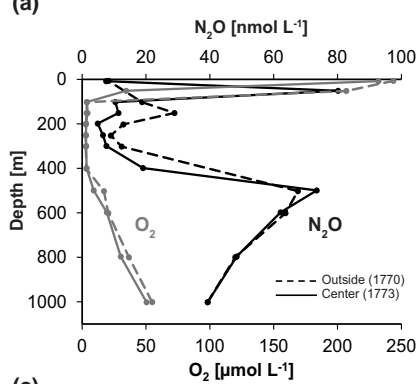

(c)

nirs $\left[\times 10^{3}\right.$ copies $\left.L^{-1}\right]$

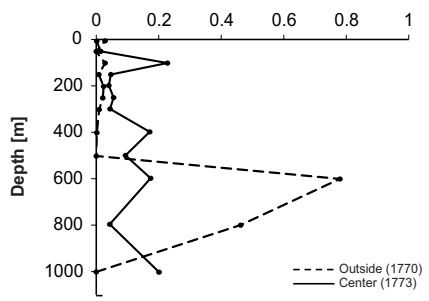

(b)

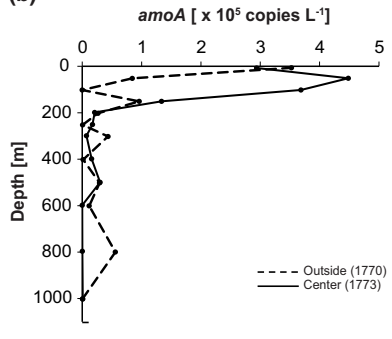

(d)

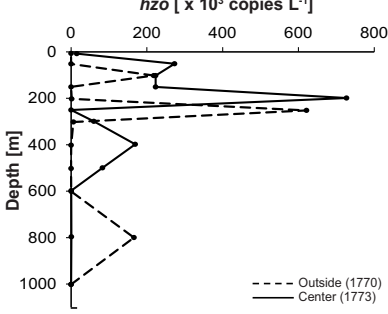

Figure 5. Vertical distribution of $\mathrm{N}_{2} \mathrm{O}$ and $\mathrm{O}_{2}$ concentrations (a), as well as gene abundance of $\operatorname{amoA}(\mathbf{b}), \operatorname{nir} S(\mathbf{c})$, and $h z o(\mathbf{d})$ within the centre (solid lines) and outside (dashed lines) of eddy A in December 2012 (M91 cruise). The numbers in parentheses indicate the station numbers (cf. Fig. 1).

centre of the eddy, the subsequent and sharp decrease in $\mathrm{O}_{2}$ concentrations led to a marked decrease in $\mathrm{N}_{2} \mathrm{O}$.

The observed $\mathrm{NO}_{3}^{-}$and $\mathrm{N}^{*}$ minima, as well as the pronounced secondary nitrite maximum (Codispoti and Packard,

1980), were consistent with the $\mathrm{N}_{2} \mathrm{O}$ distribution, suggesting the occurrence of $\mathrm{N}$-loss processes, particularly in the centre of eddy A. Abundances of the hzo gene, the functional gene marker for anaerobic ammonium oxidation (anammox) (Schmid et al., 2008), were generally higher through the water column within the centre of eddy $\mathrm{A}$, with a maximum at about 50-200 $\mathrm{m}$ depth (i.e. shallower than outside of the eddy; see Fig. 5). Although anammox does not reflect $\mathrm{N}_{2} \mathrm{O}$ consumption, it does provide an indication of active $\mathrm{N}$ loss within the OMZ of the eddy at the time of sampling (Dalsgaard et al., 2012; De Brabandere et al., 2014), which is in line with the observations from previous studies in the ETSP (Altabet et al., 2012; Stramma et al., 2013; Bourbonnais et al., 2015).

Nitrification, as indicated by the depth distribution of gene abundances of amoA, the functional key gene for archaeal ammonium oxidation (Rotthauwe et al., 1997), was observed within eddy A and was stronger in the upper $200 \mathrm{~m}$ for the centre of the eddy, whereas below $200 \mathrm{~m}$ it was of similar magnitude for stations outside and in the centre (Fig. 5). This would explain the comparatively high shallow-depth maximum of $\mathrm{N}_{2} \mathrm{O}$ within the centre of eddy A (Fig. 4). $\mathrm{N}_{2} \mathrm{O}$ production by archaeal ammonia oxidation has previously been identified to be important in subsurface waters in the ETSP (Löscher et al., 2012). The deeper $\mathrm{N}_{2} \mathrm{O}$ maximum, however, cannot be explained by nitrification alone as e.g. Kalvelage et al. (2011) showed a decrease of nitrification rates below the upper oxycline. Furthermore, the linear correlation of $\Delta \mathrm{N}_{2} \mathrm{O}$ and AOU, which is indicative of nitrification (Nevison et al., 
2003), is not present in that depth range, and geochemical tracer studies suggest a mixed $\mathrm{N}_{2} \mathrm{O}$ production from nitrification and denitrification (Löscher et al., 2012; Ryabenko et al., 2012).

Based on the structure of the vertical profiles of $a m o A$ and nirS gene abundances, we could also infer that $\mathrm{N}_{2} \mathrm{O}$ maxima at the boundaries of the OMZ resulted not only from nitrification but also partially from production during early stages of denitrification. Our observations support the results of Castro-González and Farías (2004), who used $\mathrm{N}_{2} \mathrm{O}$ production experiments in the ETSP to show that denitrifiers produce increasing $\mathrm{N}_{2} \mathrm{O}: \mathrm{N}_{2}$ ratios as the $\mathrm{O}_{2}$ concentrations increase due to the well-known sensitivity of the $\mathrm{N}_{2} \mathrm{O}$ reductase to $\mathrm{O}_{2}$ (Dalsgaard et al., 2014). In order to roughly estimate the $\mathrm{N}_{2} \mathrm{O}: \mathrm{N}_{2}$ ratios in the upper oxycline of eddy A, we used the observed $\mathrm{N}_{2} \mathrm{O}$ concentrations and $\mathrm{N}^{*}$ as an indicator of $\mathrm{N}$ loss. As a result we found that, for example, within the centre of eddy A there was a three-fold increase in the $\mathrm{N}_{2} \mathrm{O}: \mathrm{N}_{2}$ ratio for an $\mathrm{O}_{2}$ concentration decrease of about $85 \%\left(229.1 \mu \mathrm{mol} \mathrm{L}{ }^{-1}\right.$ at $20 \mathrm{~m}$ to $32.36 \mu \mathrm{mol} \mathrm{L}^{-1}$ at $\left.50 \mathrm{~m}\right)$. A similar pattern was observed for stations located outside of the eddy, although the ratios were slightly higher due to the generally higher $\mathrm{N}_{2} \mathrm{O}$ concentrations (Fig. 5). Furthermore, we also observed that in the upper $600 \mathrm{~m}$ depth the potential for $\mathrm{N}_{2} \mathrm{O}$ production via partial denitrification (as inferred from nirS abundances) was higher in the centre of the eddy than outside (Fig. 5). Nevertheless, within the OMZ's core it was evident that $\mathrm{N}_{2} \mathrm{O}$ consumption was stronger in the centre of the eddy, suggesting that, even though the genes for $\mathrm{N}_{2} \mathrm{O}$ production by denitrification were present, they were probably inhibited due to further low $\mathrm{O}_{2}$ concentrations $(\sim 3 \mu \mathrm{mol} \mathrm{L}-1)$. It is also likely, however, that under denitrifying conditions $\mathrm{N}_{2} \mathrm{O}$ depletion occurs at a faster rate than production, masking the $\mathrm{N}_{2} \mathrm{O}$ production signal. Elevated $\mathrm{NO}_{2}^{-}$concentrations $\left(11 \mu \mathrm{mol} \mathrm{L}{ }^{-1}\right)$ along with closeto-detection-limit $\mathrm{NO}_{3}^{-}$concentrations in the $\mathrm{OMZ}$ further suggest that complete - and more intense - denitrification took place in the OMZ core at the eddy centre (Codispoti and Christensen, 1985; Codispoti et al., 1986). Thus, in general, in the centre of the eddy a higher $\mathrm{N}_{2} \mathrm{O}$ maxima at the upper boundary of the OMZ resulted from enhanced nitrification and partial denitrification, whereas stronger $\mathrm{N}_{2} \mathrm{O}$ depletion at the OMZ's core resulted from enhanced, complete denitrification. Although at depths below $600 \mathrm{~m}$ both amoA and nirS gene abundances were higher outside of the eddy, $\mathrm{N}_{2} \mathrm{O}$ concentrations remained similar to those in the centre and $\mathrm{O}_{2}$ was still lower in the eddy's centre (Fig. 5). Nevertheless, vertical profiles of the same eddy 1 month before showed that $\mathrm{N}_{2} \mathrm{O}$ concentrations below $600 \mathrm{~m}$ were higher in the centre (cf. Fig. 3). Thus, it could be that increasing variability beneath the lower boundary of the OMZ was caused by decreasing intensity (velocity) of the eddy below $600 \mathrm{~m}$ (Fig. 2). Overall, the net effect of anticyclonic eddy A was an enhancement of $\mathrm{N}$-loss processes within its centre, thereby making the OMZ's core an even stronger sink for $\mathrm{N}_{2} \mathrm{O}$ than it would be under "mean" conditions.

\subsection{Effect of eddy ageing on $\mathrm{N}_{2} \mathrm{O}$}

Westward propagation of mesoscale eddies implies that properties of the waters which were "enclosed" within its centre at the time of formation are transported offshore (Chelton et al., 2007). Gruber et al. (2011), for example, suggested that this transport leads to a net reduction of primary productivity in coastal upwelling regions due to nutrient subduction and advection. Since the export of organic matter is the most important factor fuelling the $\mathrm{N}$ cycling in the OMZ (Capone and Hutchins, 2013; Babbin et al., 2014), changes in the distribution of the main production-consumption pathways of $\mathrm{N}_{2} \mathrm{O}$ are likely to occur under the influence of mesoscale eddies along their transit to open waters. In the following we compare the vertical distributions of $\mathrm{N}_{2} \mathrm{O}$ and relevant biogeochemical parameters within the centre of the young coastal eddy A during the M90 cruise, and the old openocean eddy B. Likewise, we include data of a second survey of eddy A during the M91 cruise (hereafter eddy A-M91). For the comparison we focus on the upper $600 \mathrm{~m}$ of the water column since the largest physical and biogeochemical anomalies were observed at this depth range (see Stramma et al., 2013). The cyclonic eddy $C$ is not considered for this analysis given its relatively minor importance for $\mathrm{N}$-loss processes.

Figure 6 depicts the vertical distribution of $\mathrm{N}_{2} \mathrm{O}$ from stations located at or near the centre of the eddies $\mathrm{A}, \mathrm{B}$, and A-M91. As can be seen, despite the pronounced $\mathrm{N}_{2} \mathrm{O}$ maxima at the upper and lower oxyclines in eddy A-M91, in general, the $\mathrm{N}_{2} \mathrm{O}$ concentrations within this eddy were lower than in eddy A and eddy B. Integrated concentration of $\mathrm{N}_{2} \mathrm{O}$ within the centre of eddy A was $24 \%$ higher than in eddy B (Table 1). This difference can be partially attributed to the fact that $\mathrm{N}$-cycling processes tend to decrease after subsurface nutrients are consumed and/or subducted, and primary production progressively decreases towards the open ocean. This is supported by higher $\mathrm{O}_{2}$ and $\mathrm{NO}_{3}^{-}$concentrations in eddy $\mathrm{B}$ than in eddy $\mathrm{A}$, as well as the comparatively lower $\mathrm{NO}_{2}^{-}$concentrations in eddy $\mathrm{B}$, which suggests an overall decrease in organic matter respiration in the open-ocean eddy. Although the examination of temperature-salinity plots from both cruises suggests the presence of a single water mass within the OMZ of eddies A and B (Fig. S3), with our methods it was not possible to determine the exact time and location of formation of both eddies. Thus, it cannot be ruled out that the differences in the biogeochemical conditions at the time of formation also contributed to the observed differences in $\mathrm{N}_{2} \mathrm{O}$. In a recent study, Thomsen et al. (2015) showed that the eddy-induced transport of shelf-break waters to the open ocean might be an important mechanism for the advection of $\mathrm{N}$-deficient waters away from the coastal area off Peru. Hence, even though the physical properties of both 


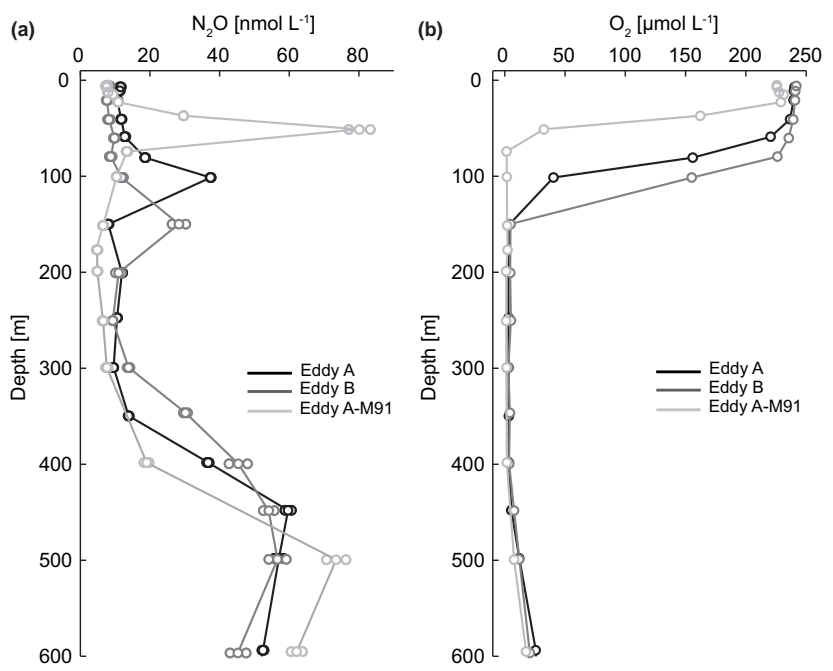

Figure 6. Vertical distribution of $\mathrm{N}_{2} \mathrm{O}$ (a) and $\mathrm{O}_{2}$ (b) within the centre of the anticyclonic eddies A, B, and A-M91. For $\mathrm{N}_{2} \mathrm{O}$ the standard deviation from triplicate samples is depicted by circles around the concentration values at each depth.

Table 1. Comparison of physical and biogeochemical properties of mode water eddies in the ETSP during the M90 (November 2012) and M91 (December 2012) cruises. $\mathrm{N}_{2} \mathrm{O}, \mathrm{O}_{2}, \mathrm{NO}_{3}^{-}, \mathrm{NO}_{2}^{-}$, and selected functional gene markers are expressed as integrated concentrations/abundances over the water column.

\begin{tabular}{|c|c|c|c|}
\hline & A(M90) & A(M91) & B(M90) \\
\hline Vertical extent $(\mathrm{m})^{\mathrm{a}}$ & $0-600$ & $0-600$ & $0-600$ \\
\hline $\operatorname{Radius}(\mathrm{km})^{\mathrm{a}}$ & 52.0 & - & 48.8 \\
\hline Volume $\left(10^{12} \mathrm{~m}^{3}\right)^{\mathrm{a}}$ & 5.2 & - & 4.7 \\
\hline $\mathrm{N}_{2} \mathrm{O}\left(\mathrm{mol} \mathrm{m}^{-2}\right)$ & 0.034 & 0.016 & 0.026 \\
\hline $\mathrm{O}_{2}\left(\mathrm{~mol} \mathrm{~m}^{-2}\right)$ & 36.4 & 10.8 & 42.9 \\
\hline $\mathrm{NO}_{3}^{-}\left(\mathrm{mol} \mathrm{m}^{-2}\right)$ & 14.8 & 12.4 & 15.8 \\
\hline $\mathrm{NO}_{2}^{-}\left(\mathrm{mol} \mathrm{m}^{-2}\right)$ & 1.6 & 2.6 & 0.52 \\
\hline amoA $\left(10^{8}\right.$ copies $\left.\mathrm{m}^{-2}\right)$ & 19.54 & 598.5 & 379.3 \\
\hline $\operatorname{nir} S\left(10^{8}\right.$ copies $\left.\mathrm{m}^{-2}\right)$ & 0.37 & 57.9 & 0.23 \\
\hline hzo $\left(10^{8}\right.$ copies $\left.\mathrm{m}^{-2}\right)$ & 4.27 & 101773 & 2.9 \\
\hline
\end{tabular}

${ }^{a}$ Values taken from Stramma et al. (2013) refer to the depth range wherein the strongest anomalies were observed.

eddies (A and $\mathrm{B}$ ) are reflected in the vertical distribution of $\mathrm{N}_{2} \mathrm{O}$, the extent to which the observed differences in $\mathrm{N}_{2} \mathrm{O}$ concentrations are the result of either decaying $\mathrm{N}$ cycling or the properties of the water masses at the time of formation remains an open question.

In comparison with eddy A-M91, the integrated concentration of $\mathrm{N}_{2} \mathrm{O}$ in the centre of eddy $\mathrm{A}$ was $53 \%$ higher (Table 1). This marked decrease of $\mathrm{N}_{2} \mathrm{O}$ in the coastal mode water eddy A only 1 month after the first sampling points towards an enhancement of $\mathrm{N}$-loss processes within the $\mathrm{OMZ}$ of this eddy. In agreement with this observation, eddy AM91 featured the lowest $\mathrm{O}_{2}$ and $\mathrm{NO}_{3}^{-}$content, as well as the highest $\mathrm{NO}_{2}^{-}$values among the three eddies considered (Table 1). Our observations are also in line with the results of Bourbonnais et al. (2015), who reported the occurrence of intense $\mathrm{N}$ loss (up to $\sim 44 \mu \mathrm{mol} \mathrm{L}^{-1}$ ) within in eddy A, as well as an increase in the vertical expansion of the $\mathrm{N}$ deficient waters in eddy A-M91. A substantial increase in water-column-integrated abundances of both amoA and nirS genes was observed in the centre of eddy A-M91 with respect to eddies $\mathrm{A}$ and $\mathrm{B}$, reflecting the comparatively higher $\mathrm{N}_{2} \mathrm{O}$ concentrations found at the boundaries of the OMZ (cf. Fig. 6). It seems, however, that enhanced $\mathrm{N}_{2} \mathrm{O}$ production by nitrification and partial denitrification in eddy A-M91 was outpaced by high $\mathrm{N}_{2} \mathrm{O}$ consumption in the core of the $\mathrm{OMZ}$ with further decreasing $\mathrm{O}_{2}$ concentrations, which in turn resulted in values even lower than those of the open-ocean eddy B. Furthermore, sharp differences in hzo gene abundances among the three eddies, with A-M91 featuring considerably higher values (Table 1), serve as evidence that $\mathrm{N}$ loss activities in the ETSP were comparatively stronger in coastal eddies at the time of sampling. Likewise this also suggests that strengthening of eddy A (increased velocity) while it stayed stationary on the shelf between the two surveys (M90 and M91) might have led to an N-cycling intensification through the water column.

\subsubsection{Changes in $\mathrm{N}$ cycling}

In order to provide a quantitative estimate of the amount of denitrification that took place in eddy $\mathrm{A}$, as well as to assess how it changed between the two surveys, in this section we present estimates of nitrate deficit $(\Delta \mathrm{N})$ by means of the "NO" approach (Naqvi and Gupta, 1985). "NO" is used as a quasi-conservative water mass tracer (Broecker, 1974) and is defined here as $\left[\mathrm{O}_{2}\right]+9.1\left[\mathrm{NO}_{3}^{-}\right]$(Bange et al., 2000). A plot of "NO" versus potential temperature $(\theta)$ from stations located at the centre of eddy A during M90 and M91 is shown in Fig. 7. For both cruises we obtained a good correlation between "NO" and $\theta$ after excluding data points from the surface to the upper limit of the OMZ $\left(\mathrm{O}_{2} \sim 20 \mu \mathrm{mol} \mathrm{L}^{-1}\right)$, as well as those from the OMZ's core $\left(\mathrm{O}_{2}<5 \mu \mathrm{molL}^{-1}\right)$. Hence, the obtained regression lines ("NO" ${ }_{M 90}$, "NO" ${ }_{M 91}$, Fig. 7) represent conditions which are expected when the OMZ is not affected by denitrification (Naqvi and Gupta, 1985). We calculated $\Delta \mathrm{N}$ by using "NO"M90 and "NO"M91 according to the following expression (Bange et al., 2000): ([“NO" $\left.{ }_{x}\right]-\left[\mathrm{O}_{2}\right] / 9.1-\left[\mathrm{NO}_{3}^{-}\right]-\left[\mathrm{NO}_{2}^{-}\right]$, where $x$ is the corresponding regression line for each cruise.

After integrating $\Delta \mathrm{N}$ over the depth range of the OMZ, we obtained values of 8.9 and $0.02 \mathrm{~mol} \mathrm{~m}^{-2}$ for eddy A during M90 and M91, respectively. $\Delta \mathrm{N}$ from M90 was significantly higher than most estimates available for a similar OMZ in the Arabian Sea (Naqvi and Gupta, 1985; Howell et al., 1997; Bange et al., 2000), and it was only comparable with values up to $7.3 \mathrm{~mol} \mathrm{~m}^{-2}$ found by Naqvi and Gupta (1985) at about $20^{\circ} \mathrm{N}$ towards the coast of Oman. $\Delta \mathrm{N}$ from M91 was, how- 


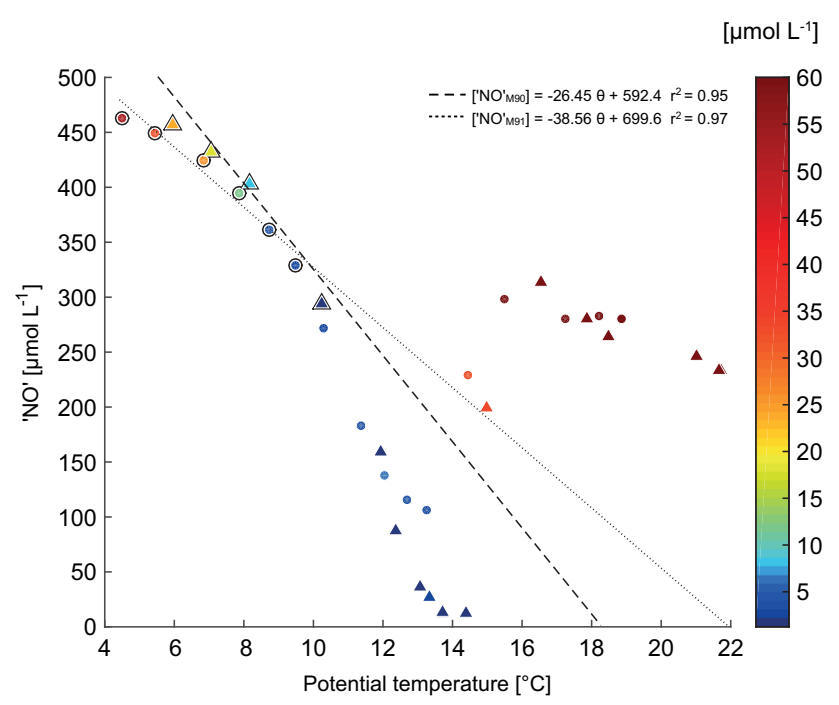

Figure 7. "NO" vs. potential temperature $(\theta)$ for stations located at the centre of eddy A during M90 (November 2012; circles) and M91 (December 2012; triangles). The color bar represents the $\mathrm{O}_{2}$ concentrations (scale has been truncated at $60 \mu \mathrm{mol} \mathrm{L}-1$ ). "NO" values from non-denitrifying waters $\left(\mathrm{O}_{2}>5 \mu \mathrm{mol} \mathrm{L}{ }^{-1}\right)$ are highlighted in black and were used for the linear least-squares regressions.

ever, markedly lower than both $\Delta \mathrm{N}$ from M90 and $\Delta \mathrm{N}$ from previous work in the $\mathrm{OMZ}$ of the Arabian Sea (minimum $\Delta \mathrm{N}=1.0 \mathrm{~mol} \mathrm{~m}^{-2}$; Bange et al., 2000). This suggests not only strong denitrification activities within mesoscale eddies formed off the Peruvian coast but also high short-term variability as they move offshore. These results are in agreement with recent work in the ETSP, in which an isotopic approach was used to show the occurrence of intense $\mathrm{N}$ loss by both denitrification and anammox in the OMZ within mesoscale eddies (Bourbonnais et al., 2015). A pronounced Chl $a$ and turbidity maximum in the centre of eddy A-M91 suggest a potentially increased supply of organic matter which, upon sinking, could stimulate $\mathrm{N}$ loss through anammox and denitrification (Kalvelage et al., 2013; De Brabandere et al., 2014). Therefore it is likely that $\mathrm{N}$ loss still took place in the coastal eddy A during M91, albeit at rates comparatively lower than those during M90 and the time period elapsed between the two cruises. Our results are in agreement with the work of Löscher et al. (2015a), who reported enhanced $\mathrm{N}_{2}$ fixation rates in the centre of mode water eddies, as well as co-occurrence of $\mathrm{N}_{2}$ fixation and $\mathrm{N}$ loss, suggesting a spatial link between both processes in the ETSP. As part of the same study, Löscher et al. (2015a) also found that in general $\mathrm{N}_{2}$-fixation rates tended to be lower during M91, most likely indicating a decline of biological production during ageing of the eddy. Hence, although $\mathrm{N}_{2}$-fixation rates were lower within the mode water eddy A during M91, its occurrence, together with the fact that during M91 we most likely sampled the eddy after a period of intense $\mathrm{N}$ cycling, might help to explain the alleviation on the $\mathrm{N}$ deficit between the M90 and M91 cruises. Under the spatial constraints of our survey, one could infer that the $\mathrm{N}$ loss during M91 (as determined both by the $\mathrm{N}^{*}$ and "NO" methods) does not necessarily reflect enhanced denitrification within the eddy at the time of sampling (December) but rather the remaining signal of denitrification during early stages of the eddy which were partially captured when we sampled it in November. However, given that we might have sampled different portions of the eddy despite a consistent definition of centre (i.e. based on SSHA data), a direct comparison remains speculative and further studies employing methods with higher temporal and spatial resolution would be required to assess the temporal variability of $\mathrm{N}$ loss and $\mathrm{N}_{2} \mathrm{O}$ consumption in the $\mathrm{OMZ}$ of mesoscale eddies.

In order to roughly estimate the amount of $\mathrm{N}$ loss through denitrification which was driven by coastal eddy A between November and December 2012 (27 days), we used our $\Delta \mathrm{N}$ values and a calculated area of $8.5 \times 10^{9} \mathrm{~m}^{2}$. This resulted in a daily loss flux of $0.04 \mathrm{Tg}-\mathrm{N} \mathrm{day}{ }^{-1}$, which if scaled to an annual basis would be comparable with values reported for the Arabian Sea by Mantoura et al. (1993) but lower than most estimates for the same area (Naqvi, 1987; Howell et al., 1997; Bange et al., 2000) and for the eastern tropical South and North Pacific (20-33 and 20-29 Tg-N yr ${ }^{-1}$, respectively; Codispoti and Richards, 1976; Codispoti and Packard, 1980; DeVries et al., 2012). However, a direct comparison with those studies is not entirely realistic since the mean lifespan of mesoscale eddies off Peru is typically not longer than a few months (Chaigneau, et al., 2008). Therefore the intense $\mathrm{N}$ loss observed within the eddies might represent a transient state which at times contributes significantly to the total $\mathrm{N}$ loss in the ETSP. Since denitrification can also be a source of $\mathrm{N}_{2} \mathrm{O}$ (Codispoti and Christensen, 1985; Bakker et al., 2014), we estimated the $\mathrm{N}_{2} \mathrm{O}$ production from denitrifying waters within the OMZ's core $\left(\mathrm{O}_{2}<5 \mu \mathrm{mol} \mathrm{L}^{-1}\right)$ of eddy A. For this, we calculated the depth-integrated $\Delta \mathrm{N}_{2} \mathrm{O}$ $\left(\mathrm{N}_{2} \mathrm{O}_{\text {measured }}-\mathrm{N}_{2} \mathrm{O}_{\text {equilibrium }}\right)$ over the OMZ for both profiles at the centre of eddy A (M90 and M91). Using the eddy area and time span between cruises as shown above, we obtained a $\mathrm{N}_{2} \mathrm{O}$ daily yield of $1.3 \times 10^{-5} \mathrm{Tg}^{-\mathrm{N}_{2}} \mathrm{O}_{\text {day }}{ }^{-1}$ (or $8.0 \times 10^{-6} \mathrm{Tg}-\mathrm{N} \mathrm{day}{ }^{-1}$ ). Scaling this value to an annual basis resulted in a $\mathrm{N}_{2} \mathrm{O}$ yield of $4.5 \times 10^{-3} \mathrm{Tg}^{-\mathrm{N}_{2}} \mathrm{O} \mathrm{yr}^{-1}$ (or $2.9 \times 10^{-3} \mathrm{Tg}_{-} \mathrm{N} \mathrm{yr}^{-1}$ ), which is markedly lower than previous values for the Arabian Sea (Mantoura et al 1993; Bange et al., 2001). Accordingly, our estimated $\mathrm{N}_{2} \mathrm{O}$ production from denitrification is considerably low in comparison with our estimated denitrification rates from eddy $\mathrm{A}$ in November-December $2012(0.02 \%)$, suggesting faster $\mathrm{N}_{2} \mathrm{O}$ consumption than production within the OMZ of eddy A for the period of sampling. $\mathrm{N}_{2} \mathrm{O}$ production in the $\mathrm{OMZ}$ of the Arabian Sea has been reported to amount to at least $2 \%$ of the mean denitrification rates (Bange et al, 2001). However this value is not entirely comparable with ours since in that study a whole basin $\left(1.95 \times 10^{12} \mathrm{~m}^{2}\right)$ is considered and our time span is in the order of months rather than years. It should be 
pointed out that our denitrification rates and $\mathrm{N}_{2} \mathrm{O}$ yields from the OMZ assume a given size and permanence period of the eddy in coastal waters and, moreover, do not take into consideration the progressive decrease in $\mathrm{N}$-loss activities within the eddy centre as it moves away from the coast. Therefore, our values are only contentious and are meant to highlight the need for combined biogeochemical-physical studies which account for the annual variability in occurrence, abundance, and spatial extent of mesoscale anticyclonic eddies off Peru, given their importance for $\mathrm{N}$-loss processes.

The coastal eddy A was formed on the shelf about 2 months before the time of sampling, whereas the open-ocean eddy B was formed at least 5 months before our survey. This hampers a direct comparison of both mode water eddies, in particular because with our methods it was not possible to determine the exact location where eddy B was formed. Nonetheless, the main physical and biogeochemical features of eddies A and B suggest that, in general, the ageing of mesoscale eddies tends to decrease $\mathrm{N}_{2} \mathrm{O}$ concentrations through the water column in response to reduced the supply of material to fuel microbial respiration in the boundaries of the OMZ.

\subsection{Synthesis}

Aside from the temporal and spatial sampling constrains, our observations allowed us to identify common features of the water column distribution of $\mathrm{N}_{2} \mathrm{O}$ that arise from the occurrence of different mesoscale eddies in the ETSP. We showed that the main vertical distribution of $\mathrm{N}_{2} \mathrm{O}$ within eddies $\mathrm{A}, \mathrm{B}$, and $\mathrm{C}$ fits well to the typical open-ocean distribution reported in previous works in the same area (Löscher et al., 2012; Ryabenko et al., 2012, Kock et al., 2016). Thus, elevated concentrations of $\mathrm{N}_{2} \mathrm{O}$ at the upper and lower boundaries of the OMZ could be attributed to production via nitrification and partial denitrification (as inferred from high amoA and nirS abundances, respectively), whereas denitrification-driven depletion of $\mathrm{N}_{2} \mathrm{O}$ was clearly observed at the core of the OMZ $\left(\mathrm{O}_{2} \sim<5 \mu \mathrm{mol} \mathrm{L}{ }^{-1}\right)$. However, vertical shifting of the $\mathrm{OMZ}$ due to isocline displacement within the eddies (both anticyclonic and cyclonic) also led to variation of the position of the maxima and minima in the water column. The upward displacement of oxycline waters with high $\mathrm{N}_{2} \mathrm{O}$ concentrations was, nevertheless, detached from surface waters, and therefore eddies did not affect the surface concentrations of $\mathrm{N}_{2} \mathrm{O}$. Concentrations of $\mathrm{N}_{2} \mathrm{O}$ were generally lower through the water column in anticyclonic eddies, suggesting that they transport highly productive waters trapped at the coast and bear a high potential for intense $\mathrm{N}$ cycling, as has been also shown by recent studies in the ETSP (Bourbonnais et al., 2015; Thomsen et al., 2015). Likewise, we observed that the vertical expansion of low- $\mathrm{O}_{2}$ waters within the core of the OMZ $\left(\mathrm{O}_{2} \sim<5 \mu \mathrm{mol} \mathrm{L}{ }^{-1}\right)$ within the centre of anticyclonic eddies also resulted in an increased area where $\mathrm{N}_{2} \mathrm{O}$ depletion was favoured. Hence mesoscale eddies in the ETSP might repre- sent a locally relevant, enhanced sink for $\mathrm{N}_{2} \mathrm{O}$. This observation is in line with previous studies which directly measured $\mathrm{N}$ loss in the same eddies (see e.g. Bourbonnais et al., 2015; Löscher et al., 2015a). The fact that OMZ core waters (which act as a sink for $\mathrm{N}_{2} \mathrm{O}$ ) are transported over long distances offshore also suggests a potentially higher relevance of this region as a sink for $\mathrm{N}_{2} \mathrm{O}$. Nevertheless, given the extremely high production of $\mathrm{N}_{2} \mathrm{O}$ in the ETSP (Kock et al., 2016) and our current lack of understanding of the overall, long-term impact of mesoscale eddies in the biogeochemistry of $\mathrm{N}_{2} \mathrm{O}$, it is, at this point, difficult to assess how relevant this sink term might be.

\section{Summary and conclusions}

In this study we used a combined approach including physical, biogeochemical, and molecular methods in order to investigate the distribution of $\mathrm{N}_{2} \mathrm{O}$ within mesoscale eddies in the ETSP. Overall, a two-peak structure was observed in vertical profiles of $\mathrm{N}_{2} \mathrm{O}$, indicating the alternation between production and consumption processes as a response to the $\mathrm{O}_{2}$ gradients through the water column. Our results suggest that $\mathrm{N}_{2} \mathrm{O}$ concentrations in the water column were consistent with the main physical features of the mesoscale eddies. Hence, lifting (deepening) of the seasonal (main) pycnoclines in mode water eddies (A and B) was visible for $\mathrm{N}_{2} \mathrm{O}$, with shoaling of the upper maxima and slight displacement of the lower maxima towards deeper depths. Likewise, doming of isopycnals in the open-ocean cyclonic eddy (C) caused a shift of the upper and lower $\mathrm{N}_{2} \mathrm{O}$ maxima towards shallower depths. $\mathrm{O}_{2}$ and nutrient $\left(\mathrm{NO}_{3}^{-}\right.$and $\left.\mathrm{NO}_{2}^{-}\right)$distributions as well as abundances of key gene markers for $\mathrm{N}_{2} \mathrm{O}$ production processes showed that the upper and lower oxyclines in the boundaries of the $\mathrm{OMZ}$ are net sources of $\mathrm{N}_{2} \mathrm{O}$, producing the two observed maxima which envelop the $\mathrm{N}_{2} \mathrm{O}$ depleted waters in the core of the OMZ. Trapping of highly productive coastal waters in anticyclonic eddies (e.g. eddy A) led to a net enhancement of N-loss processes in its centre both through denitrification and anammox, thereby making the OMZ's core an even stronger sink for $\mathrm{N}_{2} \mathrm{O}$ than it would be under mean conditions. However, the strength of the $\mathrm{N}$ cycling processes decreases during the transit of these eddies out of the shelf, mostly in response to a lower supply of organic matter from surface waters and sinking of nutrients as the eddy collapses. Hence our observations suggest that open-ocean mode water eddies tend to produce less $\mathrm{N}_{2} \mathrm{O}$ than coastal ones because the weaker maxima that enclose the OMZ core have an overall bigger impact than the reduced $\mathrm{N}_{2} \mathrm{O}$ consumption within the OMZ core. Nevertheless, water properties at the time of formation, as well as the pace at which eddies propagate, might significantly alter the $\mathrm{N}_{2} \mathrm{O}$ concentrations through the water column. Although depth distribution of $\mathrm{N}_{2} \mathrm{O}$ in the centre of cyclonic eddy $\mathrm{C}$ was similar to eddies A and B, in general the concentrations (both maxima and minima) were higher and its relative importance 
for $\mathrm{N}$ loss was negligible. Despite the observed shoaling of upper isopycnals in both mode water and cyclonic eddies, we did not find any appreciable changes in the surface distribution of $\mathrm{N}_{2} \mathrm{O}$ since these features are trapped below the mixed layer.

In conclusion, our survey provides the first insights into $\mathrm{N}_{2} \mathrm{O}$ distribution within mesoscale eddies in the ETSP and points out the importance of multidisciplinary approaches in investigating the rather multifaceted $\mathrm{N}$ cycling in OMZs. However, high complexity of the $\mathrm{N}_{2} \mathrm{O}$ production and consumption pathways, together with unaccounted temporal and spatial variability, hampers the chances of an objective quantification of the net effect of mesoscale eddies on $\mathrm{N}_{2} \mathrm{O}$ for the whole ETSP. Projected future deoxygenation and expansion of OMZs have been suggested to significantly increase marine $\mathrm{N}_{2} \mathrm{O}$ production. However, an increased strength of the $\mathrm{N}_{2} \mathrm{O}$ sink within the core of low- $\mathrm{O}_{2}$ waters in mesoscale eddies might also play an important role which has not yet been quantified. Hence, it is critical to understand how these prominent features of the circulation might affect $\mathrm{N}_{2} \mathrm{O}$ distribution and concentrations in order to be able to assess the variability of its sources and the strength of its sinks.

\section{The Supplement related to this article is available online at doi:10.5194/bg-13-1105-2016-supplement.}

Author contributions. L. Stramma, D. L. Arévalo-Martínez, and H. W. Bange conceived the study; D. L. Arévalo-Martínez set up the instrumentation for discrete $\mathrm{N}_{2} \mathrm{O}$ measurements on board the $\mathrm{R} / \mathrm{V}$ Meteor and carried out the fieldwork together with A. Kock and H. W. Bange. D. L. Arévalo-Martínez and A. Kock processed and calibrated depth profile $\mathrm{N}_{2} \mathrm{O}$ data. C. R. Löscher collected and processed the molecular data. L. Stramma processed and analysed hydrographic data. D. L. Arévalo-Martínez wrote the manuscript with contributions from H. W. Bange, A. Kock, C. R. Löscher, R. A. Schmitz, and L. Stramma.

Acknowledgements. This study was funded by the DFG-supported project SFB754 (http://www.sfb754.de), the BMBF joint project SOPRAN II and III (FKZ 03F0611A and FKZ 03F662A), and the EU FP7 project InGOS (grant agreement no. 284274). We thank the Peruvian authorities for authorizing us to conduct the study in their territorial waters. We also would like to thank our Peruvian colleagues from IMARPE (M. Graco, A. Bernal, G. Flores, and V. León) for their logistical support. We thank the captains and crew of the R/V Meteor for their assistance during the cruises M90 and M91. Likewise, we thank T. Baustian, A. Bernal, J. Craig, G. Eirund, G. Flores, V. León, M. Lohmann, N. Martogli, K. Nachtigall, and G. Krahmann for their contributions to the processing of the different data sets. The altimeter data used for Fig. 1 were produced by Ssalto/Duacs and distributed by Aviso with support from CNES.

Edited by: B. Ward

\section{References}

Altabet, M. A., Ryabenko, E., Stramma, L., Wallace, D. W. R., Frank, M., Grasse, P., and Lavik, G.: An eddy-stimulated hotspot for fixed nitrogen-loss from the Peru oxygen minimum zone, Biogeosciences, 9, 4897-4908, doi:10.5194/bg-9-48972012, 2012.

Arévalo-Martínez, D. L., Beyer, M., Krumbholz, M., Piler, I., Kock, A., Steinhoff, T., Körtzinger, A., and Bange, H. W.: A new method for continuous measurements of oceanic and atmospheric $\mathrm{N}_{2} \mathrm{O}$, $\mathrm{CO}$ and $\mathrm{CO}_{2}$ : performance of off-axis integrated cavity output spectroscopy (OA-ICOS) coupled to nondispersive infrared detection (NDIR), Ocean Sci., 9, 1071-1087, doi:10.5194/os-9-1071-2013, 2013.

Arévalo-Martínez, D. L., Kock, A., Löscher, C. R., Schmitz, R. A., and Bange, H. W.: Massive nitrous oxide emissions from the tropical South Pacific Ocean, Nat. Geosci., 8, 530-533, doi:10.1038/ngeo2469, 2015.

Babbin, A. R., Keil, R. G., Devol, A. H., and Ward, B.: Organic matter stoichiometry, flux, and oxygen control nitrogen loss in the ocean, Science, 344, 406-408, 2014.

Bakker, D. C. E., Bange, H. W., Gruber, N., Johannenssen, T., Upsill-Goddard, R. C., Borges, A. V., Delille, B., Löscher, C. R., Naqvi, S. W. A., Omar, A. O., and Santana-Casiano, J. M.: Airsea interactions of natural long-lived greenhouse gases $\left(\mathrm{CO}_{2}\right.$, $\mathrm{N}_{2} \mathrm{O}, \mathrm{CH}_{4}$ ) in a changing climate, in: Ocean-atmosphere interactions of gases and particles, edited by: Liss, P. S. and Johnson, M. T., 113-169, Springer, Heidelberg, Germany, 2014.

Bange, H. W., Rixen, T., Johansen, A. M., Siefert, R. L., Ramesh, R., Ittekkot, V., Hoffmann, M. R., and Andreae, M. O.: A revised nitrogen budget for the Arabian Sea, Global Biogeochem. Cy., 14, 1283-1297, 2000.

Bange, H. W., Rapsomanikis, S., and Andreae, M. O.: Nitrous oxide cycling in the Arabian Sea, J. Geophys. Res., 106, 1053-1065, 2001.

Bange, H. W., Freing, A., Kock, A., and Löscher, C. R.: Marine pathways to nitrous oxide, in: Nitrous oxide and climate change, edited by: Smith, K., Earthscan, London, UK, 36-62 2010.

Bourbonnais, A., Altabet, M. A., Charoenpong, C. N., Larkum, J., $\mathrm{Hu}, \mathrm{H}$. , Bange, H. W., and Stramma, L.: N-loss isotope effects in the Peru oxygen minimum zone studied using a mesoscale eddy as a natural tracer experiment, Global Biogeochem. Сy., 29, 793-811, doi:10.1002/2014GB005001, 2015.

Broecker, W. S.: "NO", a conservative water-mass tracer, Earth Planet. Sc. Lett., 23, 100-107, 1974.

Capone, D. G. and Hutchins, D. A.: Microbial biogeochemistry of coastal upwelling regimes in a changing ocean, Nat. Geosci., 6, 711-717, 2013.

Castro-González, M. and Farías, L.: $\mathrm{N}_{2} \mathrm{O}$ cycling at the core of the oxygen minimum zone off northern Chile, Mar. Ecol.-Prog. Ser., 280, 1-11, 2004.

Chaigneau, A., Gizolme, A., and Grados, C.: Mesoscale eddies off Peru in altimeter records: Identification algorithms and eddy spatio-temporal patterns, Prog. Oceanogr., 79, 106-119, 2008.

Chelton, D. B., Schlax, M. G., Samelson, R. M., and de Szoeke, R. A.: Global observations of large oceanic eddies, Geophys. Res. Lett., 34, L15606, doi:10.1029/2007GL030812, 2007. 
Chelton, D. B., Gaube, P., Schlax, M. G., Early, J. J., and Samelson, R. M.: The influence of nonlinear mesoscale eddies on nearsurface oceanic chlorophyll, Science, 334, 328-332, 2011.

Codispoti, L. A.: Interesting times for marine $\mathrm{N}_{2} \mathrm{O}$, Science, 327 , 1339-1340, 2010.

Codispoti, L. A. and Christensen, J. P.: Nitrification, denitrification and nitrous oxide cycling in the eastern tropical South Pacific Ocean, Mar. Chem., 16, 277-300, 1985.

Codispoti, L. A. and Packard, T. T.: Denitrification rates in the eastern tropical South Pacific, J. Mar. Res., 38, 453-477, 1980.

Codispoti, L. A. and Richards, F. A.: An analysis of the horizontal regime of denitrification in the eastern tropical North Pacific, Limnol. Oceanogr., 21, 379-388, 1976.

Codispoti, L. A., Friederich, G. E., Packard, T. T., Glover, H. E., Kelly, P. J., Spinrad, R. W., Barber, R. T., Elkins, J., W., Ward, B. B., Lipschultz. F., and Lostaunau, N.: High nitrite levels off northern Peru: a signal of instability in the marine denitrification rate, Science, 233, 1200-1202, 1986.

Correa-Ramirez, M. A., Hormazábal, S., and Yuras, G.: Mesoscale eddies and high chlorophyll concentrations off central Chile $\left(29^{\circ}-29^{\circ} \mathrm{S}\right)$, Geophys. Res. Lett., 34, L12604, doi:10.1029/2007GL029541, 2007.

Dalsgaard, T., Thamdrup, B., Farías, L., and Revsbech, N. P.: Anammox and denitrification in the oxygen minimum zone of the eastern South Pacific, Limnol. Oceanogr., 57, 1331-1346, 2012.

Dalsgaard, T. Stewart, F. J., Thamdrup, B., De Brabandere, L., Revsbech, N. P., Ulloa, O., Canfield, D. E., and DeLong, E. F.: Oxygen at nanomolar levels reversibly suppresses process rates and gene expression in anammox and denitrification in the oxygen minimum zone off northern Chile, mBio, 5, e01966-14, doi:10.1128/mBio.01966-14, 2014.

De Brabandere, L., Canfield, D. E., Dalsgaard, T., Friederich, G. E., Revsbech, N. P., Ulloa, O., and Thamdrup, B.: Vertical partitioning of nitrogen-loss processes across the oxic-anoxic interface of an oceanic oxygen minimum zone, Environ. Microbiol., 16, 3041-3054, 2014.

Deutsch, C., Brix, H., Ito, T., Frenzel, H., and Thompson, L.: Climate-forced variability of ocean hypoxia, Science, 333, 336339, 2011

DeVries, T., Deutsch, C., Primeau, F., Chang, B., and Devol, A.: Global rates of water-column denitrification derived from nitrogen gas measurements, Nat. Geosci., 5, 547-550, 2012.

Falkowski, P. G.: Evolution of the nitrogen cycle and its influence on the biological sequestration of $\mathrm{CO}_{2}$ in the ocean, Nature, 387 , 272-275, 1997.

Farías, L., Paulmier, A., and Gallegos, M.: Nitrous oxide and Nnutrient cycling in the oxygen minimum zone off northern Chile, Deep-Sea Res. Pt. I, 54, 164-180, 2007.

Farías, L., Castro-González, M., Cornejo, M., Charpentier, J., Faúndez, J., Boontanon, N., and Yoshida, N.: Denitrification and nitrous oxide cycling within the upper oxycline of the eastern tropical South Pacific oxygen minimum zone, Limnol. Oceanogr., 54, 132-144, 2009.

Goreau, T. J., Kaplan, W. A., Wofsky, S. C., McElroy, M. B., Valois, F. W., and Watson, S. W.: Production of $\mathrm{NO}_{2}^{-}$and $\mathrm{N}_{2} \mathrm{O}$ by nitrifying bacteria at reduced concentrations of oxygen, Appl. Environ. Microb., 40, 526-532, 1980.
Gruber, N., Lachkar, Z., Frenzel, H., Marchesiello, P., Münnich, M., McWilliams, J. C., Nagai, T., and Plattner, G.-K.: Eddy-induced reduction of biological production in eastern boundary upwelling systems, Nat. Geosci., 4, 787-792, 2011.

Hansen, H. P.: Determination of oxygen, in: Methods of Seawater Analysis, edited by: Grasshoff, K. G., Kremling, K., and Ehrhardt, M., Wiley-VCH, Weinheim, Germany, 75-90, 1999.

Howell, E. A., Doney, S. C., Fine, R. A., and Olson, D. B.: Geochemical estimates of denitrification in the Arabian Sea and the Bay of Bengal during WOCE, Geophys. Res. Lett., 24, 2549 2552, 1997.

Ji, Q., Babbin, A. R., Jayakumar, A., Oleynik, S., and Ward, B.: Nitrous oxide production by nitrification and denitrification in the Eastern Tropical South Pacific oxygen minimum zone, Geophys. Res. Lett., 42, 10755-10764, doi:10.1002/2015GL066853, 2015.

Kalvelage, T., Jensen, M. M., Contreras, S., Revsbech, N. S., Lam, P., Günter, M., LaRoche, J., Lavik, G., and Kuypers, M. M. M.: Oxygen sensitivity of anammox and coupled N-cycle processes in the oxygen minimum zones, PloS ONE, 6, e29299, doi:10.1371/journal.pone.0029299, 2011.

Kalvelage, T., Lavik, G., Lam, P., Contreras, S., Arteaga, L., Löscher, C. R., Oschlies, A., Paulmier, A., Stramma, L., and Kuypers, M. M. M.: Nitrogen cycling driven by organic matter export in the South Pacific oxygen minimum zone, Nat. Geosci. 6, 228-234, 2013.

Karstensen, J., Stramma, L., and Visbeck, M.: Oxygen minimum zones in the eastern tropical Atlantic and Pacific oceans, Prog. Oceanogr., 77, 331-350, 2008.

Kock, A., Arévalo-Martínez, D. L., Löscher, C. R., and Bange, H. W.: Extreme $\mathrm{N}_{2} \mathrm{O}$ accumulation in the coastal oxygen minimum zone off Peru, Biogeosciences, 13, 827-840, doi:10.5194/bg-13827-2016, 2016

Löscher, C. R., Kock, A., Könneke, M., LaRoche, J., Bange, H. W., and Schmitz, R. A.: Production of oceanic nitrous oxide by ammonia-oxidizing archaea, Biogeosciences, 9, 2419-2429, doi:10.5194/bg-9-2419-2012, 2012.

Löscher, C. R., Großkopf, T., Desai, F. D., Gill, D., Schunck, H., Croot, P. L., Schlosser, C., Neulinger, S. C., Pinnow, N., Lavik, G., Kuypers, M. M. M., LaRoche, J., and Schmitz, R. A.: Facets of diazotrophy in the oxygen minimum zone waters off Peru, ISME J., 8, 2180-2192, 2014.

Löscher, C. R., Bourbonnais, A., Dekaezemacker, J., Charoenpong, C. N., Altabet, M. A., Bange, H. W., Czeschel, R., Hoffmann, C., and Schmitz, R. A.: $\mathrm{N}_{2}$ fixation in eddies of the eastern tropical South Pacific Ocean, Biogeosciences Discuss., 12, 1894518972, doi:10.5194/bgd-12-18945-2015, 2015a.

Löscher, C. R., Bange, H. W., Schmitz, R. A., Callbeck, C. M. Engel, A., Hauss, H., Kanzow, T., Kiko, R., Lavik, G., Loginova, A., Melzner, F., Neulinger, S. C., Pahlow, M., Riebesell, U., Schunck, H., Thomsen, S., and Wagner, H.: Water column biogeochemistry of oxygen minimum zones in the eastern tropical North Atlantic and eastern tropical South Pacific Oceans, Biogeosciences Discuss., 12, 4495-4556, doi:10.5194/bgd-12-44952015, 2015b

McGillicuddy Jr., D. J., Anderson, L. A., Bates, N. R., Bibby, T., Buesseler, K. O., Carlson, C. A., Davis, C. S., Ewart, C., Falkowski, P. G., Goldthwait, S. A., Hansell, D. A., Jenkins, W. J., Johnson, R., Kosnyrev, V. K., Ledwell, J. R., Li, Q. P., Siegel, D. A., and Steinberg, D. K.: Eddy/wind interactions stimulate 
extraordinary mid-ocean plankton blooms, Science, 316, 10211026, 2007.

Mantoura, R. F. C., Law, C. S., Owens, N. J. P., Burkill, P. H., Woodward, E. M. S., Howland, R. J. M., and Llewellyn, C. A.: Nitrogen biogeochemical cycling in the northwestern Indian Ocean, Deep-Sea Res. Pt. II, 40, 651-671, 1993.

Myhre, G. D., Schindell, D., Bréon, F.-M., Collins, W., Fuglestvedt, J., Huang, J., Koch, D., Lamarque, J.-F., Lee, D., Mendoza, B., Nakajima, T., Robock, A., Stephens, G., Takemura, T., and Zhang, H.: Anthropogenic and natural radiative forcing, in: Climate Change 2013: The Physical Science Basis, Contribution of Working Group I to the Fifth Assessment Report of the Intergovernmental Panel on Climate Change, edited by: Stocker, T. F., Qin, D., Plattner, G.-K., Tignor, M., Allen, S. K., Boschung, J., Nauels, A., Xia, Y., Bex, V., and Midgley, P. M., Cambridge University Press, Cambridge, UK and New York, USA, 129-234, 2013.

Naqvi, S. W. A.: Some aspects of the oxygen-deficient conditions and denitrification in the Arabian Sea, J. Mar. Res., 45, 10491072, 1987.

Naqvi, S. W. A. and Gupta, R. S.: "NO", a useful tool for the estimation of nitrate deficits in the Arabian Sea, Deep-Sea. Res., 32, 665-674, 1985.

Naqvi, S. W. A., Bange, H. W., Farías, L., Monteiro, P. M. S., Scranton, M. I., and Zhang, J.: Marine hypoxia/anoxia as a source of $\mathrm{CH}_{4}$ and $\mathrm{N}_{2} \mathrm{O}$, Biogeosciences, 7, 2159-2190, doi:10.5194/bg7-2159-2010, 2010.

Nevison, C. D., Butler, J. H., and Elkins, J. W: Global distribution of $\mathrm{N}_{2} \mathrm{O}$ and the $\Delta \mathrm{N}_{2} \mathrm{O}$-AOU yield in the subsurface ocean, Global Biogeochem. Cy., 17, 1119, doi:10.1029/2003GB002068, 2003.

Paulmier, A., Ruiz-Pino, D., and Garcon, V.: The oxygen minimum zone (OMZ) off Chile as an intense source of $\mathrm{CO}_{2}$ and $\mathrm{N}_{2} \mathrm{O}$, Cont. Shelf. Res., 28, 2746-2756, 2008.

Ravishankara, A. R., Daniel, J. S., and Portmann, R. W.: Nitrous oxide $\left(\mathrm{N}_{2} \mathrm{O}\right)$ : The dominant ozone-depleting substance emitted in the 21st Century, Science, 326, 123-125, 2009.

Rotthauwe, J. H., Witzel, K. P., and Liesack, W.: The ammonia monooxygenase structural gene amoA as a functional marker: molecular fine-scale analysis of natural ammonia-oxidizing populations, Appl. Environ. Microb., 63, 4704-4712, 1997.
Ryabenko, E., Kock, A., Bange, H. W., Altabet, M. A., and Wallace, D. W. R.: Contrasting biogeochemistry of nitrogen in the Atlantic and Pacific Oxygen Minimum Zones, Biogeosciences, 9, 203215, doi:10.5194/bg-9-203-2012, 2012.

Schmid, M. C., Hooper, A. B., Klotz, M. G., Woebken, D., Lam, P., Kuypers, M. M. M., Pommerening-Roeser, A., Op den Camp, H. J. M., and Jetten, M. S. M.: Environmental detection of octahaem cytochrome c hydroxylamine/hydrazine oxidoreductase genes of aerobic and anaerobic ammonium-oxidizing bacteria, Environ. Microbiol., 10, 3140-3149, 2008.

Stramma, L., Schmidtko, S., Levin, L. A., and Johnson, G. C.: Ocean oxygen minima expansions and their biological impacts, Deep-Sea Res. Pt. I, 57, 587-595, 2010.

Stramma, L., Bange, H. W., Czeschel, R., Lorenzo, A., and Frank, M.: On the role of mesoscale eddies for the biological productivity and biogeochemistry in the eastern tropical Pacific Ocean off Peru, Biogeosciences, 10, 7293-7306, doi:10.5194/bg-10-72932013, 2013.

Stramma, L., Weller, R. A., Czeschel, R., and Bigorre, S.: Eddies and an extreme water mass anomaly observed in the eastern south Pacific at the Stratus mooring, J. Geophys. Res.-Oceans, 119, 1068-1083, 2014.

Suntharalingam, P., Sarmiento, J. L., and Toggweiler, J. R.: Global significance of nitrous-oxide production and transport from oceanic low-oxygen zones: a modeling study, Global Biogeochem. Cy., 14, 1353-1370, 2000.

Thomsen, S., Kanzow, T., Krahmann, G., Greatbatch, R. J., Dengler, M., and Lavik, G.: The formation of a subsurface anticyclonic eddy in the Peru-Chile Undercurrent and its impact on the nearcoastal salinity, oxygen and nutrient distributions, J. Geophys. Res.-Oceans, 120, doi:10.1002/2015JC010878, 2015.

Walter, S., Breitenbach, U., Bange, H. W., Nausch, G., and Wallace, D. W. R.: Distribution of $\mathrm{N}_{2} \mathrm{O}$ in the Baltic Sea during transition from anoxic to oxic conditions, Biogeosciences, 3, 557-570, doi:10.5194/bg-3-557-2006, 2006.

Welschmeyer, N.: Fluorometric analysis of Chlorophyll a in the presence of Chlorophyll b and phaeopigments, Limnol. Oceanogr. 39, 1985-1992, 1994. 